\title{
Summer and winter living coccolithophores in the Yellow Sea and the East China Sea
}

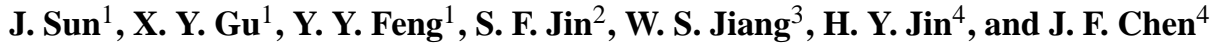 \\ ${ }^{1}$ College of Marine Science and Engineering, Tianjin University of Science and Technology, Tianjin, 300457, China \\ ${ }^{2}$ East China Sea Fisheries Research Institute, Chinese Academy of Fishery Sciences, Shanghai, 200090, China \\ ${ }^{3}$ Physical Oceanography Laboratory, Ocean University of China, Qingdao, 266003, China \\ ${ }^{4}$ Second Institute of Oceanography, State Oceanic Administration, Hangzhou, 310012, China
}

Correspondence to: J. Sun (phytoplankton@163.com)

Received: 19 March 2013 - Published in Biogeosciences Discuss.: 3 May 2013

Revised: 4 December 2013 - Accepted: 12 December 2013 - Published: 10 February 2014

\begin{abstract}
This paper describes the distribution of living coccolithophores (LCs) in the Yellow Sea and the East China Sea in summer and winter, and its relationship with environmental factors by canonical correspondence analysis (CCA). We carried out a series of investigations on LCs distribution in the Yellow Sea and the East China Sea in July and December 2011. 210 samples from different depths were collected from 44 stations in summer and 217 samples were collected from 45 stations in winter. Totally 20 taxa belonging to coccolithophyceae were identified using a polarized microscope at the $1000 \times$ magnification. The dominant species of the two seasons were Gephyrocapsa oceanica, Emiliania huxleyi, Helicosphaera carteri, and Algirosphaera robusta. In summer the abundance of coccolithophore cells and coccoliths ranged 0-176.40 cells $\mathrm{mL}^{-1}$, and $0-2144.98$ coccoliths $\mathrm{mL}^{-1}$, with the average values of 8.45 cells $\mathrm{mL}^{-1}$, and 265.42 coccoliths $\mathrm{mL}^{-1}$ respectively. And in winter the abundance of cells and coccoliths ranged $0-71.66$ cells $\mathrm{mL}^{-1}, \quad$ and $\quad 0-4698.99$ coccoliths $\mathrm{mL}^{-1}$, with the average values of 13.91 cells $\mathrm{mL}^{-1}$ and 872.56 coccoliths $\mathrm{mL}^{-1}$, respectively. In summer, the LCs in surface layer were mainly observed on the coastal belt and southern part of the survey area. In winter, the LCs in surface layer had high value in the continental shelf area of section $\mathrm{P}$. The comparison among section A, section F, section $\mathrm{P}$ and section $\mathrm{E}$ indicated lower species diversity and less abundance in the Yellow Sea than those in the East China Sea in both seasons. Temperature and the nitrate concentration may be the major environmental factors
\end{abstract}

controlling the distribution and species composition of LCs in the studying area based on CCA.

Abbreviations: LCs: Living Coccolithophores; CCA: canonical correspondence analysis; DCM: Deep Chlorophyll Maximum

\section{Introduction}

As an important phytoplankton functional group in the ocean, by conducting both photosynthesis to absorb $\mathrm{CO}_{2}$ from the atmosphere and calcification to form calcium carbonate coccoliths and release $\mathrm{CO}_{2}$ back into the atmosphere, living coccolithophores usually flourish in the open ocean, and sometimes form large blooms that can be viewed by satellites for the white light reflection from the coccolith both detached and enclosed in the coccospheres (Holligan et al., 1983; Brown and Yoder, 1994). Thus, coccolithophores take on major roles in the marine carbon cycle and it is necessary to understand the ecological distribution of individual species of living coccolithophores (Sun, 2007).

As West Pacific marginal seas, the East China Sea and the Yellow Sea not only have the eutrophic water near the coast, but also the oligotrophic water mainly caused by the Kuroshio; moreover, phytoplankton productivity is in general high in these areas, supporting the important fishery on the near shore and in the slope sea. There have been many studies on phytoplankton assemblages since the mid-20th century (e.g., Riley, 1957; Okada, 1971), especially Hulburt (1962, 1963a and b, 1964, 1970, 1990) and Marshall (1966, 1968, 
1969a and b, 1973, 1976), but few studies on modern coccolithophores have been carried out in the China Sea areas.

In the current research, we reported the abundance, composition and correlation between species and environmental parameters from a cubic view of the water layers from two seasons in order to understand the ecological role of living coccolithophores in these regions.

\section{Material and methods}

\subsection{Survey area and sampling method}

We carried out a series of comprehensive investigations including hydrology, geology, chemistry and biology in the Yellow Sea and the East China Sea $\left(27.4^{\circ} \mathrm{N} \sim 36.4^{\circ} \mathrm{N}\right.$, $121.3^{\circ} \mathrm{E} \sim 127.3^{\circ} \mathrm{E}$ ) from 6 to 24 July 2011 and 20 December 2011 to 12 January 2012, respectively. A total of 44 stations in summer and 45 stations in winter were investigated (Fig. 1).

Water samples from each station were taken by a Rosette sampler system with attached Seabird CTD (conductivity, temperature and depth) profiler. For each sample $300 \mathrm{~mL}$ to one liter of seawater were filtered onto polycarbonate filters ( $25 \mathrm{~mm}$ diameter, $0.22 \mu \mathrm{m}$ ) under less than $20 \mathrm{~mm} \mathrm{Hg}$ filtration pressure. The filters were then transferred onto plastic Petri dishes for air-drying. The dried filters were clipped and then immobilized on glass slides using Neutral balsam for laboratory microscopic analysis.

\subsection{Coccolith and coccosphere data analysis and statistical methods}

The samples were investigated using a Motic Polarizing Microscope (PM, BA300) under $1000 \times$ magnification with more than 300 coccoliths or 100 coccospheres being identified and counted per filter according to Heimdal (1997), Bollmann et al. (2002), Yang et al. (2003), Jordan et al. (2004) and Frada et al. (2010).

Coccolith/coccosphere abundance was calculated following the method described in Sun et al. (2011) as the following equation:

$A=\frac{a \times S}{N \times b \times s}$,

where $A$ is the abundance of the species; $N$ is the number of fields counted in each filter; $a$ is the number of total cells of a species in the whole viewing field of a filter; $b$ is the volume of the water filtered $(\mathrm{mL}) ; S$ is the effective filtration area; and $s$ is the area per field under $1000 \times$ magnification. The biovolumes of coccolithophore were calculated by standard geometric models (Sun and Liu, 2003), and the carbon biomass was calculated using Eppley's formula (Eppley et al., 1970).

Coccolith/coccosphere dominance index $(Y)$ and relative abundance $(P)$ were calculated following the methodology of Sun et al. $(2003,2011)$ :

$$
\begin{aligned}
Y & =\frac{n_{i}}{N} f_{i} \\
P & =\frac{n_{i}}{N}
\end{aligned}
$$

in which $Y$ is the dominance index; $N$ is the total number of cells of all species counted; $n_{i}$ is the number of cells of the species $i ; P$ is the relative abundance; and $f_{i}$ is the frequency of occurrence of the species $i$ in each sample.

A multivariate analysis, the Canonical Correspondence Analysis (CCA), was performed to infer the relationship between a set of environmental factors (temperature, salinity, nitrate, nitrite, ammonium, phosphate, silicate and sampling depth) and the species abundance (Braak, 1986). In the CCA diagram, the environmental factors are indicated by different arrow lines. The length of the arrow line represents the correlation between a certain environmental factor and the distribution of the community and species. The longer the line is, the larger the correlation is. The angle of the arrow line and the axes stands for the correlation between a certain environmental factor and the axes. The smaller the angle is, the larger the correlation is. There was no transformation of data before applying the CCA.

\section{Results}

\subsection{Environmental parameters}

The surface temperature and salinity distribution are shown in Fig. 2. In general, lower temperature and salinity were observed in the Yellow Sea than the East China Sea. The Yangtze River estuary coast was affected by the Yangtze River diluted water with low temperature and low salinity, especially in summer, and the high temperature and high salinity offshore from the East China Sea were mainly caused by the Kuroshio. Thus the cold eutrophic water with low salinity near the coast and the warm oligotrophic water with high salinity caused by the Kuroshio determine the basic hydrological pattern in the East China Sea areas (Chen, 1996).

The temperature and salinity vertical distribution of four major sections in the two seasons are shown in Figs. 3 and 4 , respectively. In summer, the distribution of the temperature and salinity presented obvious stratification. Below $40 \mathrm{~m}$ depth in the north of section A, the Yellow Sea Cold Water Mass (YSCW) was formed with relatively low temperature and high salinity $\left(T<9{ }^{\circ} \mathrm{C}, S>32\right)$ (Fig. 3). In winter, the temperature and salinity shared a similar trend, increasing from the coast to the offshore area, and due to the intensive vertical mixing, temperature and salinity showed no significant change in the water column (Fig. 4). 

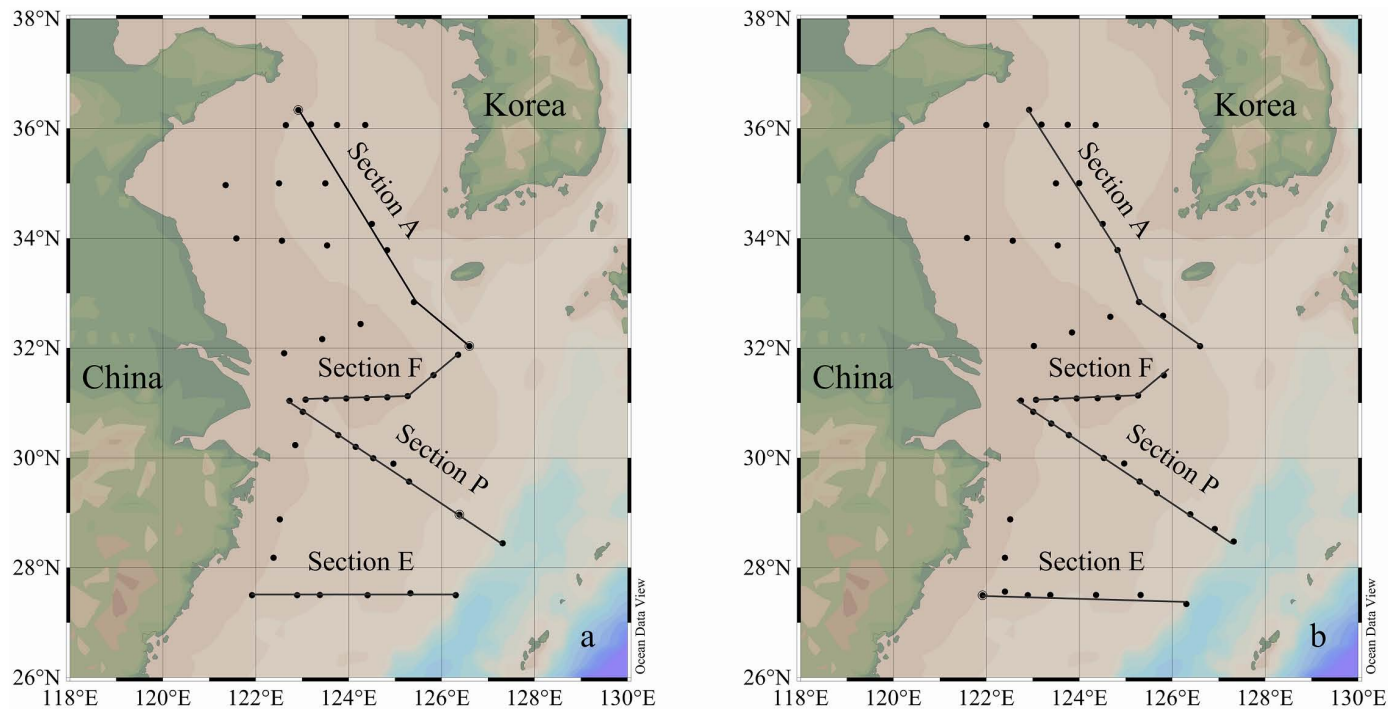

Fig. 1. Sampling stations of living coccolithophores in the Yellow Sea and East China Sea in summer and winter, 2011. (a) In summer; (b) in winter.
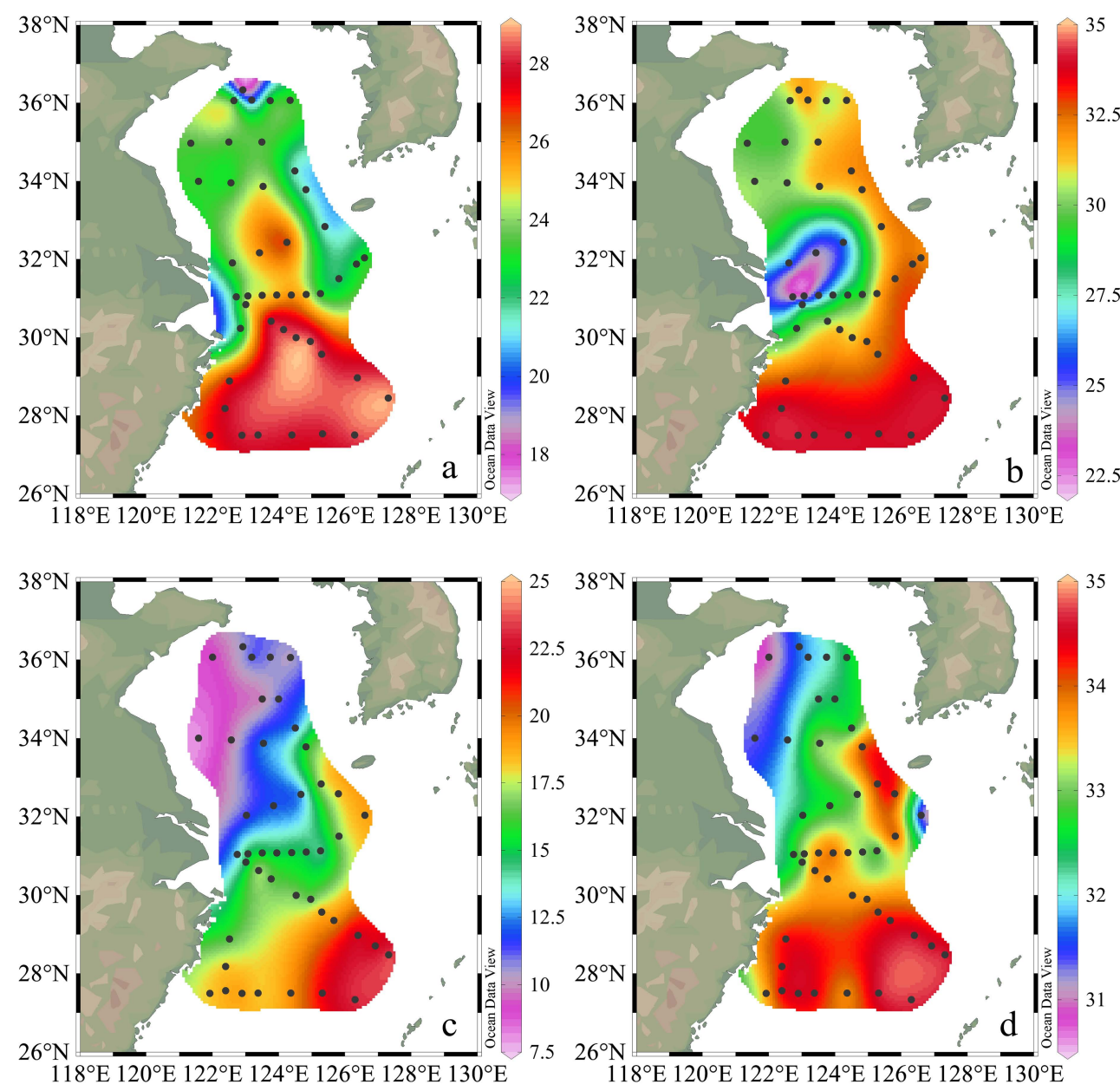

Fig. 2. The distribution of temperature and salinity in the surface layer in summer and winter. (a) Temperature distribution in summer $\left({ }^{\circ} \mathrm{C}\right)$; (b) Salinity distribution in summer (psu); (c) Temperature distribution in winter $\left({ }^{\circ} \mathrm{C}\right)$; (d) Salinity distribution in winter (psu). 

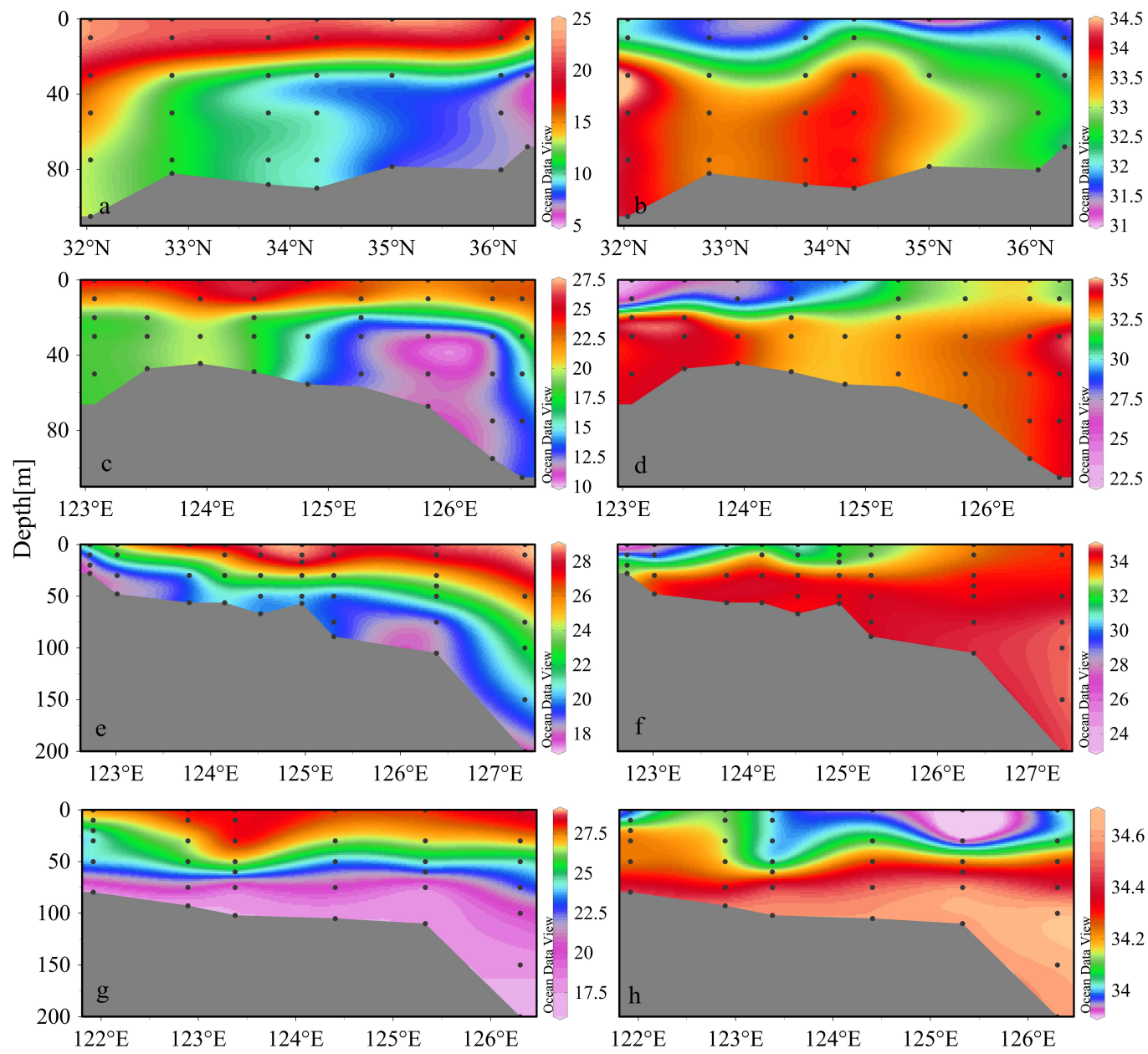

Fig. 3. Vertical distribution of temperature and salinity along the four sections in summer. (a) Temperature distribution along section $\mathrm{A}\left({ }^{\circ} \mathrm{C}\right)$; (b) Salinity distribution along section A (psu); (c) Temperature distribution along section F ( ${ }^{\circ} \mathrm{C}$ ); (d) Salinity distribution along section F (psu); (e) Temperature distribution along section $\mathrm{P}\left({ }^{\circ} \mathrm{C}\right)$; (f) Salinity distribution along section $\mathrm{P}$ (psu); (g) Temperature distribution along section $\mathrm{E}\left({ }^{\circ} \mathrm{C}\right)$; (h) Salinity distribution along section $\mathrm{E}$ (psu).

\subsection{LC species in the survey area}

In summer, a total of 13 taxa were identified in the survey area. The common taxa observed were Gephyrocapsa oceanica, Emiliania huxleyi, Helicosphaera carteri, Algirosphaera robusta and Calcidiscus leptoporus. For coccoliths, Gephyrocapsa oceanica and Emiliania huxleyi were overwhelmingly dominant, with high frequencies of $93.07 \%$ and $92.08 \%$, and the summed relative abundance was $98.65 \%$. Additionally, Helicosphaera carteri had a high frequency of $50.00 \%$, while the relative abundance was as low as $1.07 \%$. For coccospheres, Gephyrocapsa oceanica and Emiliania huxleyi were the dominant species, with high frequencies of $68.81 \%$ and $55.94 \%$, respectively (Table 1 ).

In winter, 20 taxa were identified and the common taxa were the same as those observed in summer. Gephyrocapsa oceanica and Emiliania huxleyi were still the dominant species. In addition, Braarudosphaera bigelowii had a higher frequency of occurrence in winter (Table 2).

\subsection{Horizontal distribution of common species}

In summer, the vertically integrated abundance of coccoliths and coccolithophore cells ranged

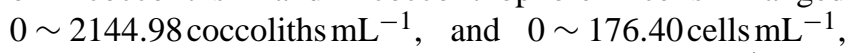
with average values of 265.42 coccoliths $\mathrm{mL}^{-1}$ and 8.45 cells mL $^{-1}$, respectively. The vertically integrated abundance of Gephyrocapsa oceanica coccoliths ranged $0 \sim 1729.09$ coccoliths $\mathrm{mL}^{-1}, \quad$ averaged at 156.56 coccoliths $\mathrm{mL}^{-1}$; the vertically integrated abundance of Emiliania huxleyi coccoliths ranged $0 \sim 1029.00$ coccoliths $\mathrm{mL}^{-1}$, and the average value was 105.27 coccoliths $\mathrm{mL}^{-1}$; and the vertically integrated abundance of Helicosphaera carteri coccoliths was $0 \sim 36.75$ coccoliths $\mathrm{mL}^{-1}$, averaged at 

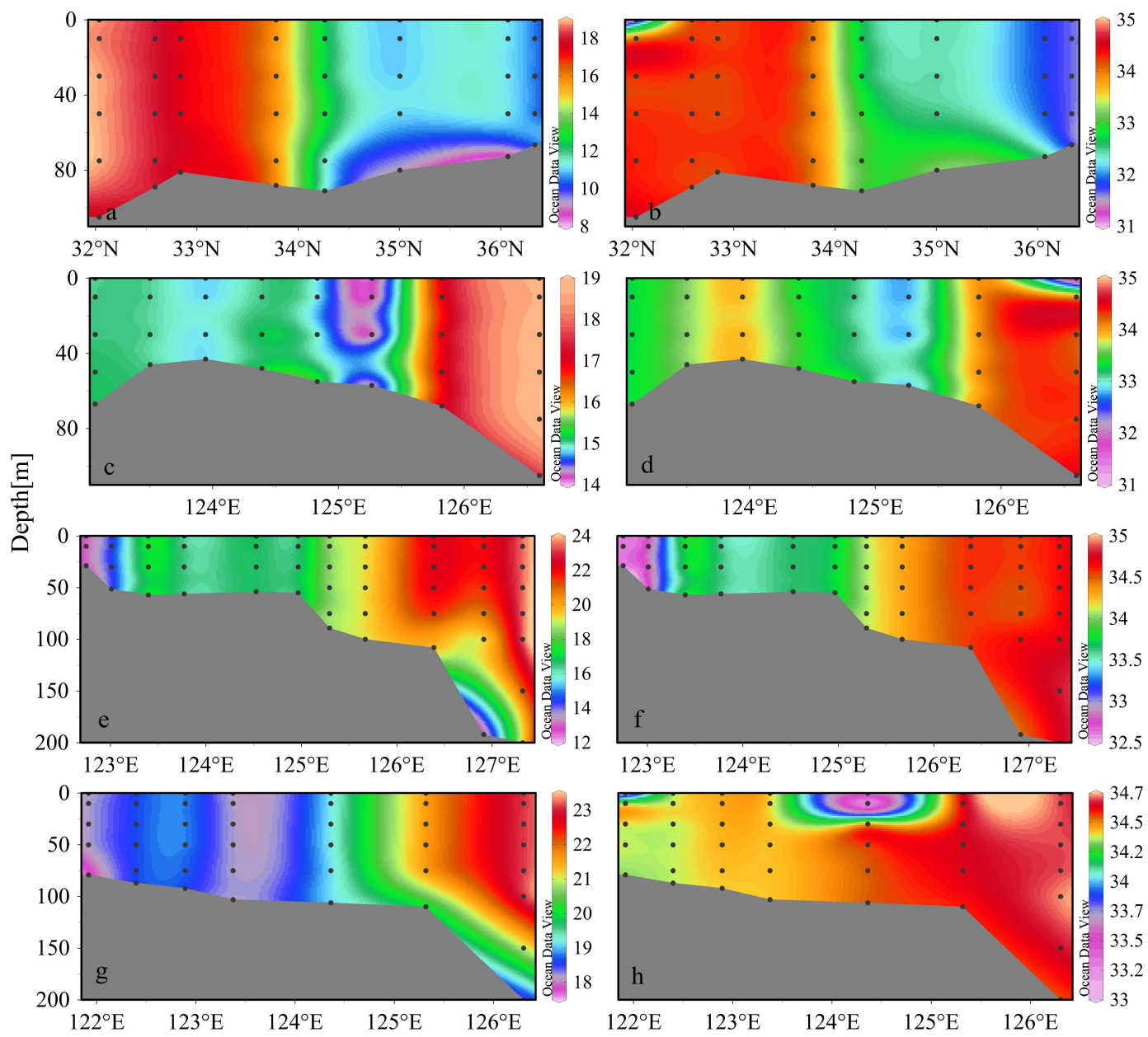

Fig. 4. Vertical distribution of temperature and salinity along the four sections in winter. (a) Temperature distribution along section $\mathrm{A}\left({ }^{\circ} \mathrm{C}\right)$; (b) Salinity distribution along section A (psu); (c) Temperature distribution along section F $\left({ }^{\circ} \mathrm{C}\right.$ ); (d) Salinity distribution along section $\mathrm{F}$ (psu); (e) Temperature distribution along section $\mathrm{P}\left({ }^{\circ} \mathrm{C}\right)$; (f) Salinity distribution along section $\mathrm{P}$ (psu); (g) Temperature distribution along section $\mathrm{E}\left({ }^{\circ} \mathrm{C}\right)$; (h) Salinity distribution along section $\mathrm{E}$ (psu).

2.83 coccoliths $\mathrm{mL}^{-1}$. As for the vertically integrated coccosphere abundances, Gephyrocapsa oceanica cell abundance ranged $0 \sim 69.83$ cells $\mathrm{mL}^{-1}$, with an average value of 4.38 cells $\mathrm{mL}^{-1}$; the abundance of Emiliania huxleyi cells ranged $0 \sim 58.80$ cells $\mathrm{mL}^{-1}$, averaged at 2.12 cells $\mathrm{mL}^{-1}$; and Algirosphaera robusta cell abundance ranged $0 \sim 47.78$ cells $\mathrm{mL}^{-1}$, averaged at $1.11 \mathrm{cells} \mathrm{mL}^{-1}$.

In winter, the vertically integrated abundance of coccoliths and cells ranged $0 \sim 4698.99$ coccoliths $\mathrm{mL}^{-1}$, and $0 \sim 71.66 \mathrm{cells} \mathrm{mL}^{-1}$, with average values of 872.56 coccoliths $\mathrm{mL}^{-1}$ and 13.91 cells $\mathrm{mL}^{-1}$, respectively. The coccolith abundance ranged $0 \sim$ 2370.38 coccoliths $\mathrm{mL}^{-1}$ for Gephyrocapsa oceanica, averaged at 484.89 coccoliths $\mathrm{mL}^{-1}$; the Emiliania huxleyi coccolith abundance ranged $0 \sim 2260.13$ coccoliths $\mathrm{mL}^{-1}$, averaged at 365.00 coccoliths $\mathrm{mL}^{-1}$; and the abundance of Braarudosphaera bigelowii coccoliths ranged from 0 to 16.54 coccoliths $\mathrm{mL}^{-1}$, averaged at 1.02 coccoliths $\mathrm{mL}^{-1}$.
The vertically integrated coccosphere abundance, $0 \sim 51.45$ cells mL $^{-1}$ for Gephyrocapsa oceanica, with an average value of 7.05 cells $\mathrm{mL}^{-1}$, and the Emiliania huxleyi cell abundance ranged $0 \sim 31.85$ cells $\mathrm{mL}^{-1}$, with an average value of 4.84 cells $\mathrm{mL}^{-1}$.

The surface layer distributions of coccolith and coccosphere in summer are shown in Fig. 5 and Fig. 6a, respectively. The abundance of Gephyrocapsa oceanica coccoliths ranged $0 \sim 463.05$ coccoliths $\mathrm{mL}^{-1}$, averaged at 29.71 coccoliths $\mathrm{mL}^{-1}$; the abundance of Emiliania huxleyi coccoliths ranged $0 \sim 286.65$ coccoliths $\mathrm{mL}^{-1}$, and the average value was 16.55 coccoliths $\mathrm{mL}^{-1}$. Gephyrocapsa oceanica and Emiliania huxleyi presented obvious ribbon distribution in the coastal area of the Yellow Sea and East China Sea, with the highest value observed in stations northeast of the Yangtze River estuary. For Helicosphaera carteri, the highest value was found southwest of Jeju Island (Fig. 5). The abundance of dominant species Gephyrocapsa ocean- 
Table 1. Living coccolithophore species composition of the Yellow Sea and East China Sea in summer, 2011.

\begin{tabular}{llll}
\hline Species & $\begin{array}{l}\text { Frequency of } \\
\text { occurrence (fi) }\end{array}$ & $\begin{array}{l}\text { Relative } \\
\text { abundance (P) }\end{array}$ & $\begin{array}{l}\text { Dominance } \\
\text { index (Y) }\end{array}$ \\
\hline Coccolith dominant species & & & \\
Gephyrocapsa oceanica & $93.07 \%$ & $59.04 \%$ & 0.5494561 \\
Emiliania huxleyi & $92.08 \%$ & $39.61 \%$ & 0.3647127 \\
Helicosphaera carteri & $50.00 \%$ & $1.07 \%$ & 0.0053287 \\
Calcidiscus leptoporus & $17.33 \%$ & $0.16 \%$ & 0.0002719 \\
\hline Coccolithophore dominant species & & \\
Gephyrocapsa oceanica & $68.81 \%$ & $50.97 \%$ & 0.3507418 \\
Emiliania huxleyi & $55.94 \%$ & $24.63 \%$ & 0.1377727 \\
Algirosphaera robusta & $31.19 \%$ & $12.88 \%$ & 0.0401645 \\
Helicosphaera carteri & $15.84 \%$ & $4.24 \%$ & 0.0067235 \\
Calcidiscus leptoporus & $11.39 \%$ & $2.56 \%$ & 0.0029089 \\
Umbilicosphaera sibogae & $5.94 \%$ & $1.48 \%$ & 0.0008770 \\
Syracosphaera spp. & $5.94 \%$ & $1.45 \%$ & 0.0008590 \\
\hline
\end{tabular}

Table 2. Living coccolithophore species composition of the Yellow Sea and East China Sea in winter, 2011.

\begin{tabular}{lcll}
\hline Species & $\begin{array}{l}\text { Frequency of } \\
\text { occurrence (fi) }\end{array}$ & $\begin{array}{l}\text { Relative } \\
\text { abundance (P) }\end{array}$ & $\begin{array}{l}\text { Dominance } \\
\text { index (Y) }\end{array}$ \\
\hline Coccolith dominant species & & & \\
Gephyrocapsa oceanica & $98.62 \%$ & $56.72 \%$ & 0.5593388 \\
Emiliania huxleyi & $96.31 \%$ & $41.83 \%$ & 0.4028726 \\
Helicosphaera carteri & $68.66 \%$ & $1.08 \%$ & 0.0073966 \\
Calcidiscus leptoporus & $40.09 \%$ & $0.15 \%$ & 0.0006089 \\
Braarudosphaera bigelowii & $27.65 \%$ & $0.12 \%$ & 0.0003242 \\
Umbilicosphaera sibogae & $19.35 \%$ & $0.06 \%$ & 0.0001172 \\
\hline Coccolithophore dominant species & & & \\
Gephyrocapsa oceanica & $80.65 \%$ & $50.69 \%$ & 0.4087761 \\
Emiliania huxleyi & $68.66 \%$ & $34.82 \%$ & 0.2390601 \\
Algirosphaera robusta & $29.95 \%$ & $6.47 \%$ & 0.0193885 \\
Helicosphaera carteri & $19.35 \%$ & $3.36 \%$ & 0.0065052 \\
Calcidiscus leptoporus & $6.45 \%$ & $0.74 \%$ & 0.0004788 \\
Umbilicosphaera sibogae & $6.45 \%$ & $0.85 \%$ & 0.0005461 \\
Braarudosphaera bigelowii & $4.15 \%$ & $0.44 \%$ & 0.0001812 \\
\hline
\end{tabular}

ica cells ranged from 0 to 23.28 cells $\mathrm{mL}^{-1}$, with an average value of 2.35 cells $\mathrm{mL}^{-1}$; the cell abundance of the other dominant species Emiliania huxleyi ranged from 0 to 7.35 cells $\mathrm{mL}^{-1}$, with an average value of 0.90 cells $\mathrm{mL}^{-1}$ (Fig. 6a). Higher abundances were mainly observed in the southern part of the survey area. The abundance distribution of the two dominant species showed a similar trend of increasing from north to south. The distributions of vertically integrated coccolithophore carbon biomass in summer are shown in Fig. 6b. The summed coccolithophore carbon biomass was mainly contributed by the distribution species Gephyrocapsa oceanica and Calcidiscus leptoporus, presenting a trend of decreasing from southeast to northwest $\left(1.4 \sim 866.7 \mathrm{gC} \mathrm{m}^{-2}\right.$, with an average value of $22.2 \mathrm{gC} \mathrm{m}^{-2}$ ). The vertically integrated carbon biomass of the other dominant species Emiliania huxleyi increased significantly from north to south $\left(135 t o \sim 8621 \mathrm{mg} \mathrm{C} \mathrm{m}^{-2}\right)$. However, due to the relatively smaller cellular biovolume, Emiliania huxleyi coccolithophores only contributed an average of $\sim 8 \%$ of the total carbon biomass in the survey area. 


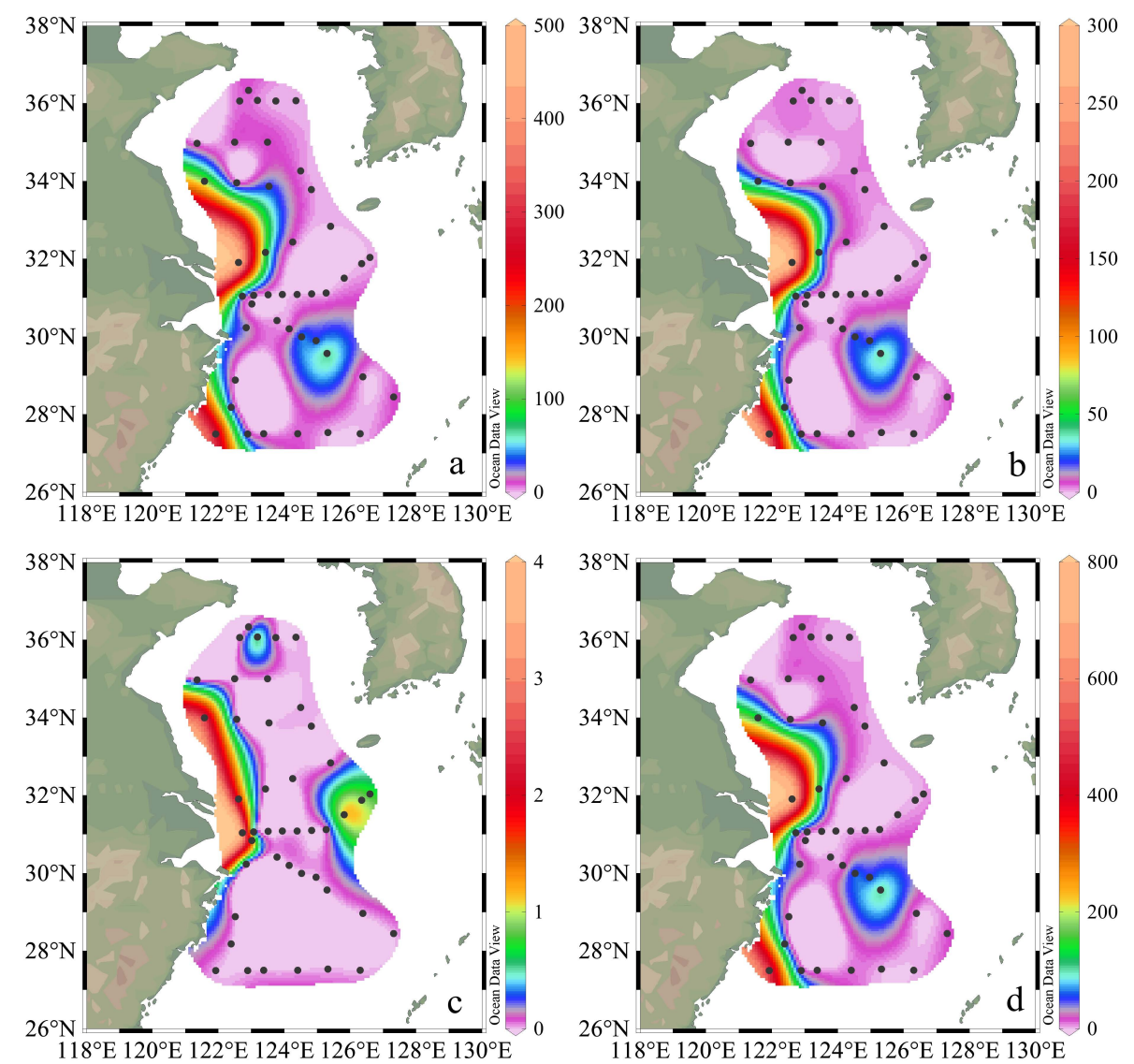

Fig. 5. The abundance distribution of coccolith on the surface layer in summer (unit: coccoliths $\mathrm{mL}^{-1}$ ). (a) Gephyrocapsa oceanica; (b) Emiliania huxleyi; (c) Helicosphaera carteri; and (d) sum.

In winter, the abundance of Gephyrocapsa oceanica coccoliths in the surface layer ranged $0 \sim 1405.69$ coccoliths $\mathrm{mL}^{-1}$, with an average value of 413.04 coccoliths $\mathrm{mL}^{-1}$; the surface layer abundance of Emiliania huxleyi coccoliths ranged $0 \sim 1455.30$ coccoliths $\mathrm{mL}^{-1}$, and the average value was 301.68 coccoliths $\mathrm{mL}^{-1}$, in general higher than those observed in summer. The higher values were observed in stations northwest of Jeju Island and southeast of the Yangtze River estuary. For Helicosphaera carteri, the high values presented obvious ribbon distribution along the western edge of the survey region (Fig. 7). The abundance of dominant species Gephyrocapsa oceanica cells ranged from 0 to 19.60 cells $\mathrm{mL}^{-1}$, with an average value of 6.08 cells $\mathrm{mL}^{-1}$; the abundance the other dominant species Emiliania huxleyi cells ranged $0 \sim 18.38$ cells $\mathrm{mL}^{-1}$ and averaged at 3.77 cells $\mathrm{mL}^{-1}$ (Fig. 8a). Higher values were mainly observed offshore and southwest of the survey area. As for the vertically integrated coccolithophore carbon (Fig. 8b), Gephyrocapsa oceanica contributed $\sim 51 \%$ of the water column total carbon biomass, especially in the western and southern sections in the survey area, where the integrated total carbon biomass reached up to $89 \mathrm{gC} \mathrm{m}^{-2}$. The summed coccolithophore carbon biomass ranged from 0.5 to $88.5 \mathrm{gC} \mathrm{m}^{-2}$, with an average value at $28.8 \mathrm{gC} \mathrm{m}^{-2}$. In the survey area, the carbon biomass of coccolithophores in winter was slightly higher than in summer; this is because of higher coccolithophore carbon biomass in the southeastern part of the study area in winter. It indicated that much more warm-water coccosphere species were being brought by the intrusion of Kuroshio in winter in this region.

\subsection{Vertical distribution of LCs at different sections}

\subsection{Vertical distribution of LCs at section A}

Section A is located from north of the Yellow Sea to northeast of the East China Sea, across the Yellow Sea. In summer, the abundance of coccoliths ranged $0 \sim 1679.48$ coccoliths $\mathrm{mL}^{-1}$, with an average of 215.57 coccoliths $\mathrm{mL}^{-1}$. The abundance of coccoliths 

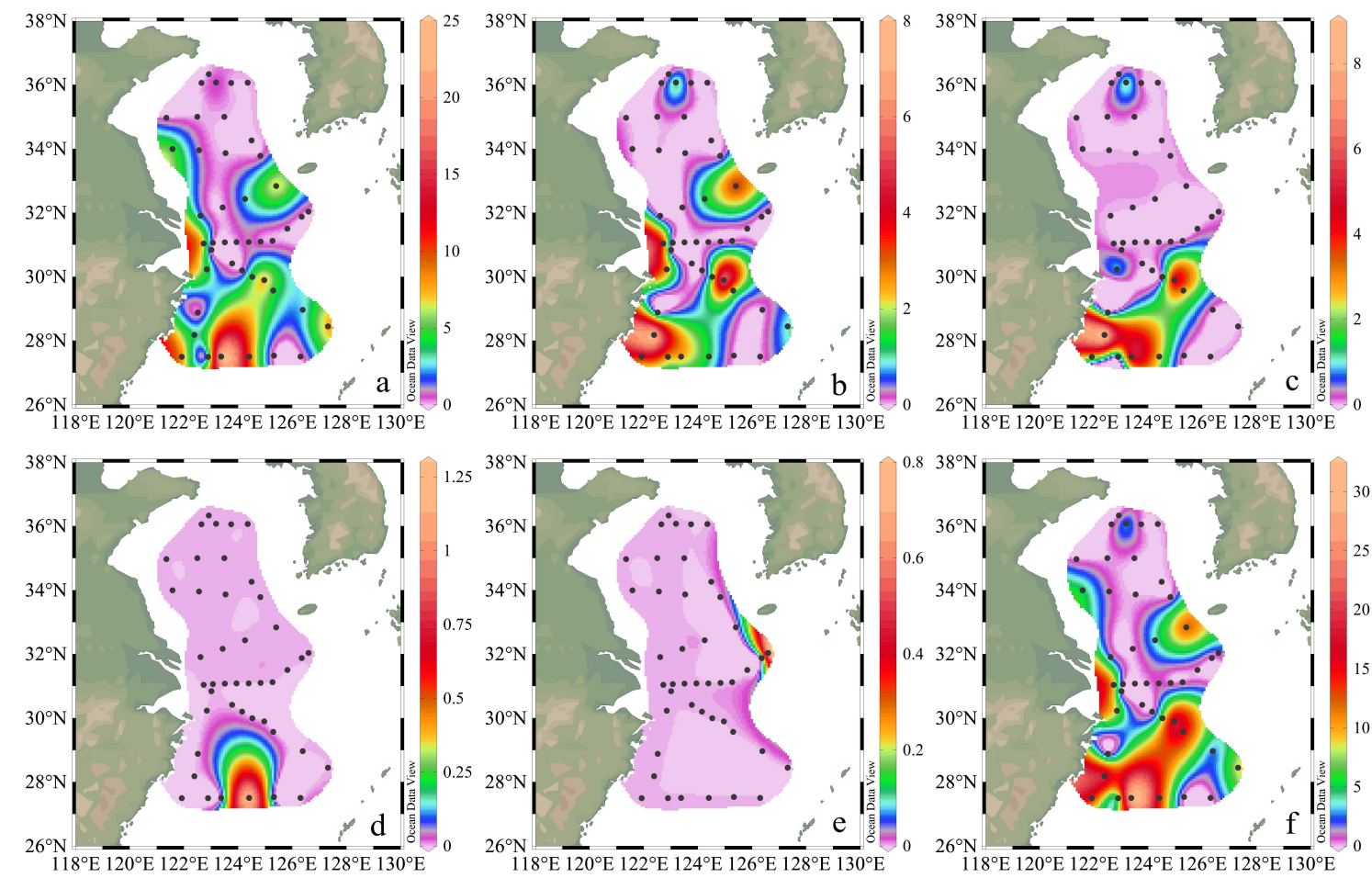

Fig. 6a. The abundance distribution of the coccosphere on the surface layer in summer (unit: cells $\mathrm{mL}^{-1}$ ). (a) Gephyrocapsa oceanica; (b) Emiliania huxleyi; (c) Algirosphaera robusta; (d) Calcidiscus leptoporus; (e) Helicosphaera carteri; and (f) sum.
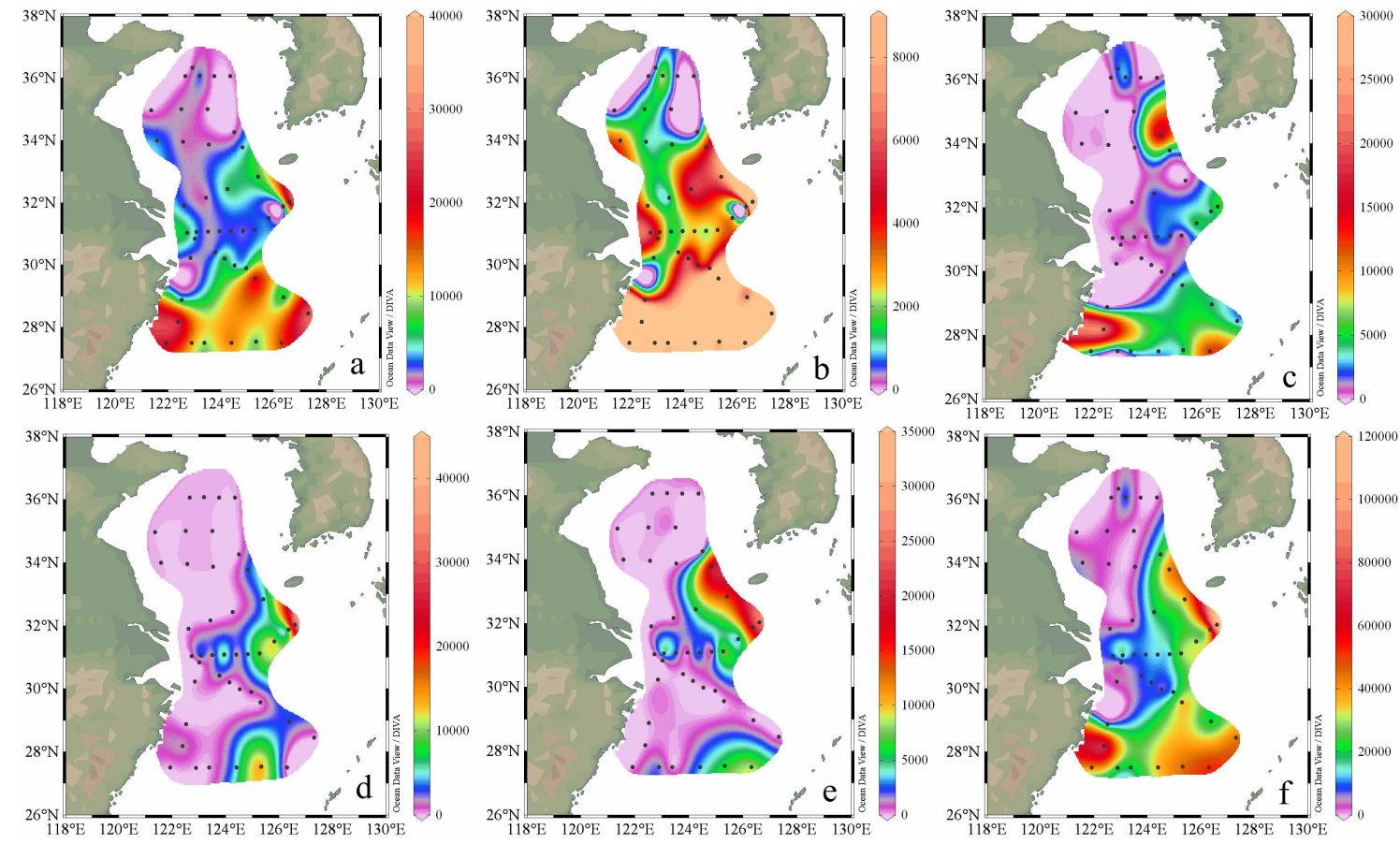

Fig. 6b. The water column vertically integrated carbon biomass distribution of the coccosphere in summer (unit: $\mathrm{mgC}^{-2}$ ). (a) Gephyrocapsa oceanica; (b) Emiliania huxleyi; (c) Algirosphaera robusta; (d) Calcidiscus leptoporus; (e) Helicosphaera carteri; and (f) sum. 


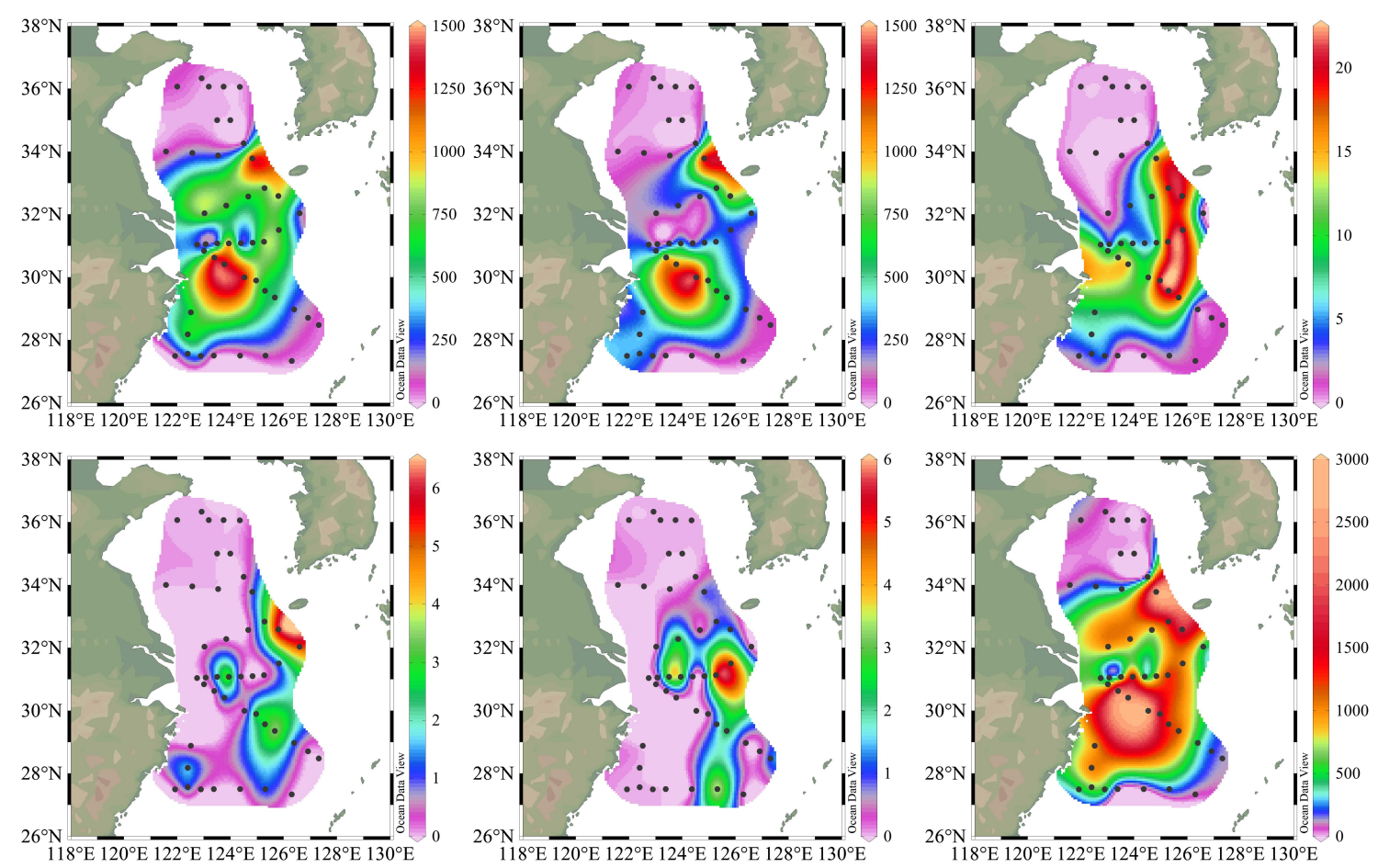

Fig. 7. The abundance distribution of coccolith on the surface layer in winter (unit: coccoliths $\mathrm{mL}^{-1}$ ). (a) Gephyrocapsa oceanica; (b) Emiliania huxleyi; (c) Helicosphaera carteri; (d) Calcidiscus leptoporus; (e) Braarudosphaera bigelowii; and (f) sum.

was in general less than 200 coccoliths $\mathrm{mL}^{-1}$, increasing from north to south and from surface to depth along this section (Fig. 9). Relatively higher values were found in the southern part of the section. The cell abundances ranged $0 \sim 53.29$ cells $\mathrm{mL}^{-1}$, with an average of 7.98 cells $\mathrm{mL}^{-1}$ (Fig. 10a). The summed cell abundance had a similar trend to coccoliths. However, a higher abundance of Algirosphaera robusta was observed in the low temperature and high salinity region, with an abundance of more than 3 cells $\mathrm{mL}^{-1}$. The number of species identified increased from 3 along the coast to 8 in the southeast, with a general increasing trend from north to south. Similarly, the calculated coccolithophore carbon biomass also kept increasing from north to south along this section, with the highest value (up to $2552 \mu \mathrm{gCL}^{-1}$ ) observed in the water depth between 65 to $100 \mathrm{~m}$ at the southern end (Fig. 10b). The distribution of total carbon biomass was mainly contributed by species Gephyrocapsa oceanica, Helicosphaera carteri and Calcidiscus leptoporus in the south and Algirosphaera robusta towards the northern section (Fig. 10b).

In winter, the abundance of coccoliths ranged $0 \sim 3698.89$ coccoliths $\mathrm{mL}^{-1}$, with an average value of 924.17 coccoliths $\mathrm{mL}^{-1}$, and mainly distributed in the southern section of the survey area (Fig. 11). The coccosphere cell abundances ranged $0 \sim 40.23$ cells mL $\mathrm{s}^{-1}$, averaged at 9.75 cells $\mathrm{mL}^{-1}$ (Fig. 12a). Relatively higher values were also found in the southern part, with a general increasing trend from north to south. However, an obvious abundance was observed in the north, with an abundance of more than 3 cells $\mathrm{mL}^{-1}$. The number of species identified increased from 3 along the coast to 9 in the southeast. The total coccolithophore carbon biomass in section A was in general lower that the level in summer (Fig. 12b). The highest value of $1849 \mu \mathrm{gC} \mathrm{L}^{-1}$ was observed in the bottom layer at $\sim 37^{\circ} \mathrm{N}$, mainly contributed by Gephyrocapsa oceanica, Helicosphaera carteri and Calcidiscus leptoporus.

\subsection{Vertical distribution of LCs at section F}

Section $F$ is affected by the Yangtze River diluted water. In summer, the abundance of coccoliths ranged from 0 to 1492.05 coccoliths $\mathrm{mL}^{-1}$, with an average value of 294.68 coccoliths $\mathrm{mL}^{-1}$. The cell abundance ranged $0 \sim$ 26.95 cells $\mathrm{mL}^{-1}$, with an average value of 6.78 cells $^{\mathrm{mL}} \mathrm{m}^{-1}$. The distribution of coccolith abundance presented an obvious layering phenomenon, increasing with sampling depth (Fig. 13), and the distribution of coccosphere cells was similar to that of coccoliths (Fig. 14a). The calculated vertical coccolithophore carbon biomass also presented the same trend of increasing with sampling depth, with the highest observed at $\sim 50 \mathrm{~m}$ between $125^{\circ} \mathrm{E}$ and $126^{\circ} \mathrm{E}$, mostly contributed by the species Helicosphaera carteri and Calcidiscus leptoporus (Fig. 14b).

In winter, the abundance of coccoliths ranged from 159.86 to 2451.23 coccoliths $\mathrm{mL}^{-1}$, with an average value of 1130.42 coccoliths $\mathrm{mL}^{-1}$, and the cell abundance 

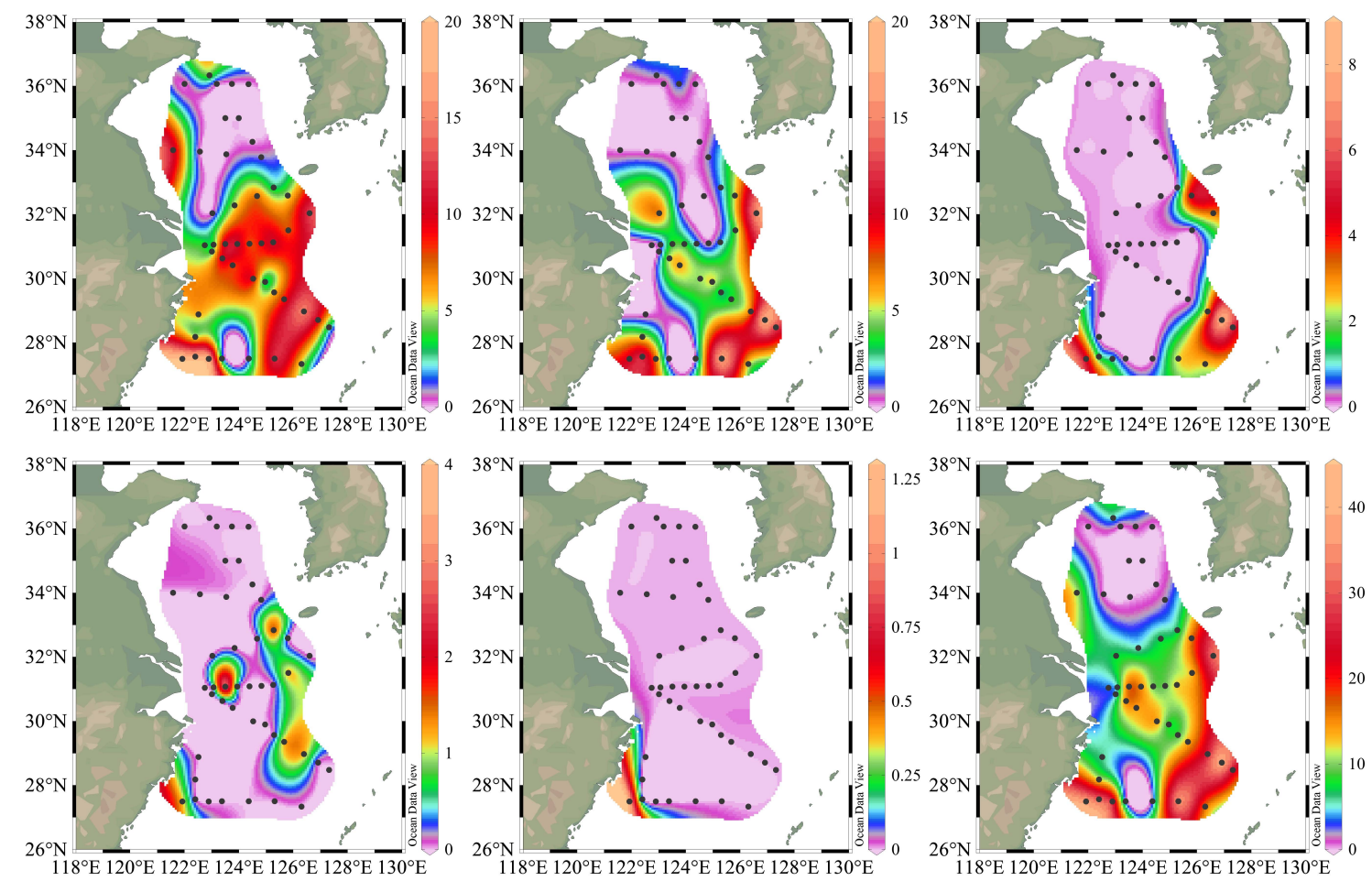

Fig. 8a. The abundance distribution of the coccosphere on the surface layer in winter (unit: cells $\mathrm{mL}^{-1}$ ). (a) Gephyrocapsa oceanica; (b) Emiliania huxleyi; (c) Algirosphaera robusta; (d) Helicosphaera carteri; (e) Calcidiscus leptoporus; and (f) sum.

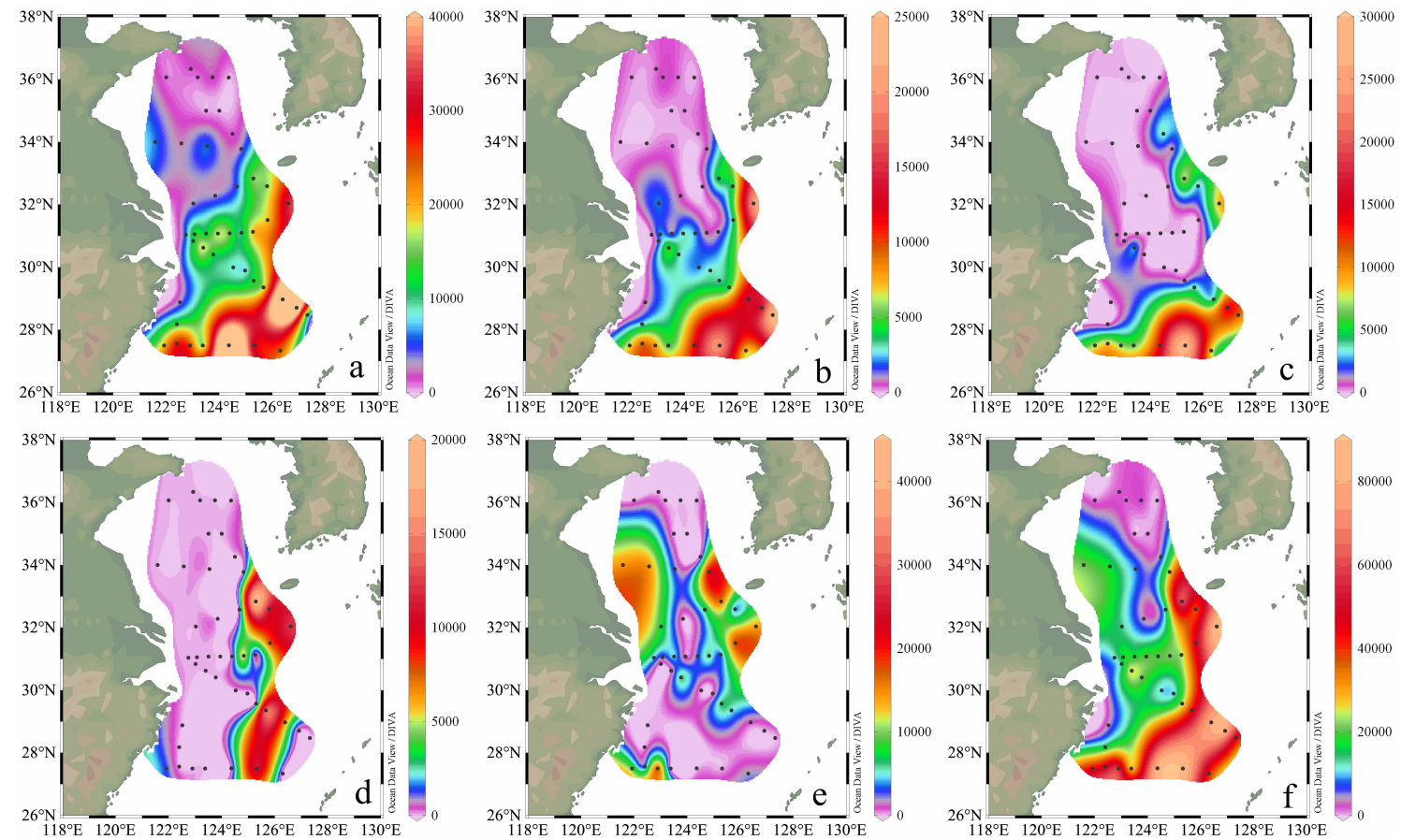

Fig. 8b. The water column vertically integrated carbon biomass distribution of the coccosphere in winter (unit: $\mathrm{mgC} \mathrm{m}^{-2}$ ). (a) Gephyrocapsa oceanica; (b) Emiliania huxleyi; (c) Algirosphaera robusta; (d) Calcidiscus leptoporus; (e) Helicosphaera carteri; and (f) sum. 

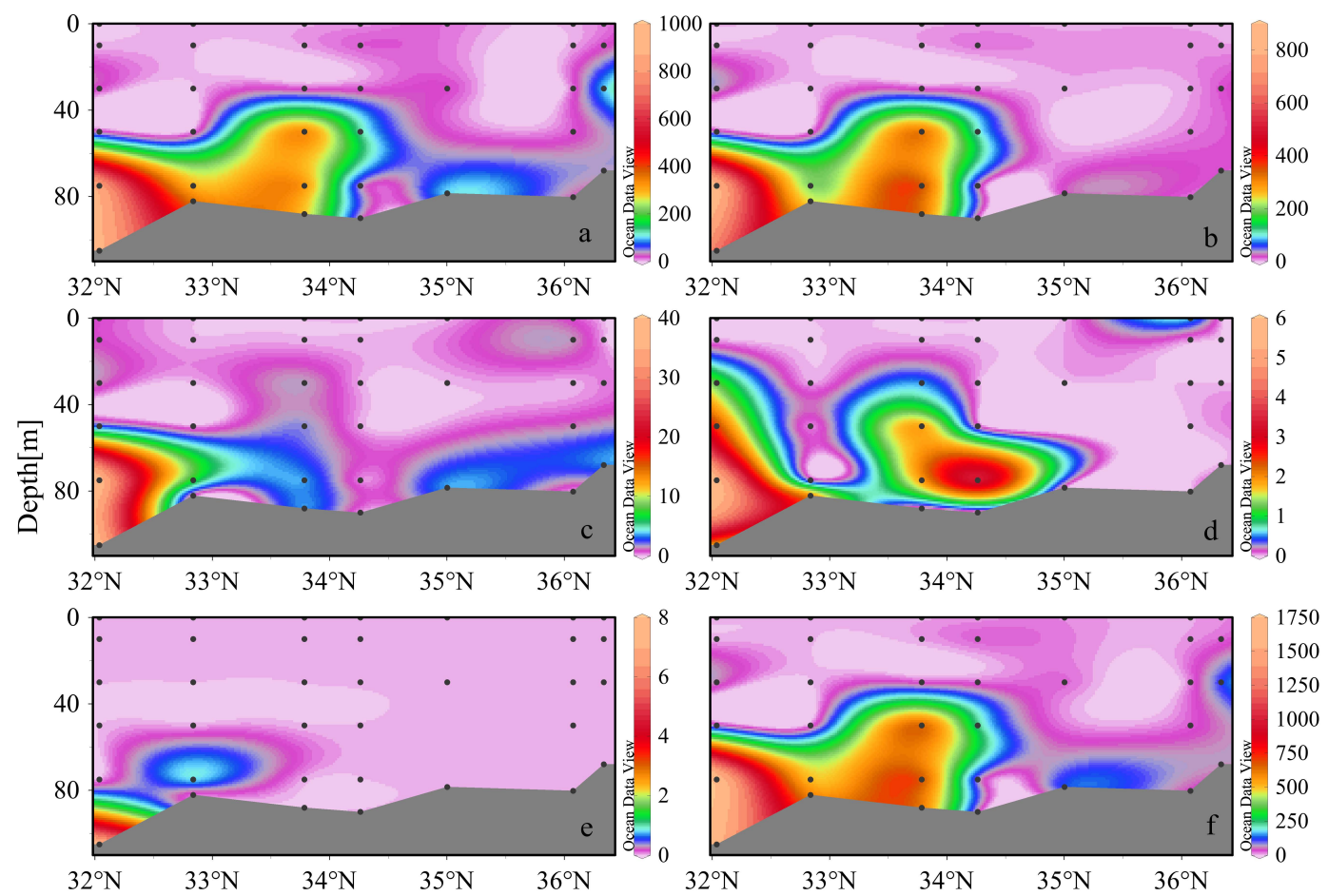

Fig. 9. Vertical distribution of coccolith abundance along section A in summer (unit: coccoliths $\mathrm{mL}^{-1}$ ). (a) Gephyrocapsa oceanica; (b) Emiliania huxleyi; (c) Helicosphaera carteri; (d) Calcidiscus leptoporus; (e) Braarudosphaera bigelowii; and (f) sum.

ranged $3.68 \sim 36.75$ cells $\mathrm{mL}^{-1}$, with an average value of 14.65 cells $\mathrm{mL}^{-1}$. The distribution of summed coccolith abundance mainly presented an increasing trend with sampling depth (Fig. 15). Differently, the highest summed coccosphere cell abundance was observed at $60 \mathrm{~m}$ depth in the eastern section, mainly determined by the dominant species Emiliania huxleyi cell distribution (Fig. 16a). The calculated vertical coccolithophore carbon biomass showed similar distribution with coccosphere cell abundance, with the highest value found at a depth of $\sim 50 \mathrm{~m}$ at the eastern edge of the section, mainly contributed by Gephyrocapsa oceanica, Helicosphaera carteri and Calcidiscus leptoporus (Fig. 16b). Compared with the vertical distribution in summer, the carbon biomass in the surface layer was higher in winter.

\subsection{Vertical distribution of LCs at section P}

Along section $\mathrm{P}$, the summer abundance of coccoliths ranged $0 \sim 2144.98$ coccoliths $\mathrm{mL}^{-1}$, with an average value of 362.86 coccoliths $\mathrm{mL}^{-1}$, with an obvious trend of increasing from surface to bottom (Fig. 17). Highest values were observed along continental shelves. The abundance of coccospheres was $0 \sim 30.63$ cells $\mathrm{mL}^{-1}$, with an average value of 8.93 cells mL $^{-1}$ (Fig. 18a). The number of species identified increased from 3 along the coast to 10 at the offshore stations, with a general increasing trend from nearshore to offshore areas. The highest carbon biomass was also found in the offshore area in the bottom layer between $125^{\circ} \mathrm{E}$ and $126^{\circ} \mathrm{E}$, contributed by the biomass of Helicosphaera carteri and Calcidiscus leptoporus (Fig. 18b). Vertically, the coccolithophore carbon biomass in general increased from surface to the bottom along this section in summer.

In winter, the abundance of coccoliths ranged $18.38 \sim 4698.99$ coccoliths $\mathrm{mL}^{-1}$, and the average value was 1270.67 coccoliths $\mathrm{mL}^{-1}$, with a decreasing trend towards offshore (Fig. 19). The highest abundance was observed along continental shelves. The abundance of coccosphere cells ranged $1.23 \sim 53.29$ cells $\mathrm{mL}^{-1}$, with an average value of 17.93 cells $\mathrm{mL}^{-1}$, mainly dominated by two species of Gephyrocapsa oceanica and Emiliania huxleyi, with the highest abundance found close to the surface in the offshore area (Fig. 20a). The number of species identified increased from 4 along the coast to 16 at the offshore stations, with a general increasing trend from nearshore to offshore areas. Similarly, the total coccolithophore carbon biomass also increased from nearshore towards offshore. Gephyrocapsa oceanica was the species that mostly determined the carbon biomass distribution (Fig. 20b).

\subsection{Vertical distribution of LCs at section $E$}

Section E is located in the southernmost part of the survey area. In summer, the abundance of coccoliths and cells ranged $0 \sim 1804.23$ coccoliths $\mathrm{mL}^{-1}$ and $0 \sim$ 39.47 cells $\mathrm{mL}^{-1}$, with an average of 178.83 coccoliths $\mathrm{mL}^{-1}$ 

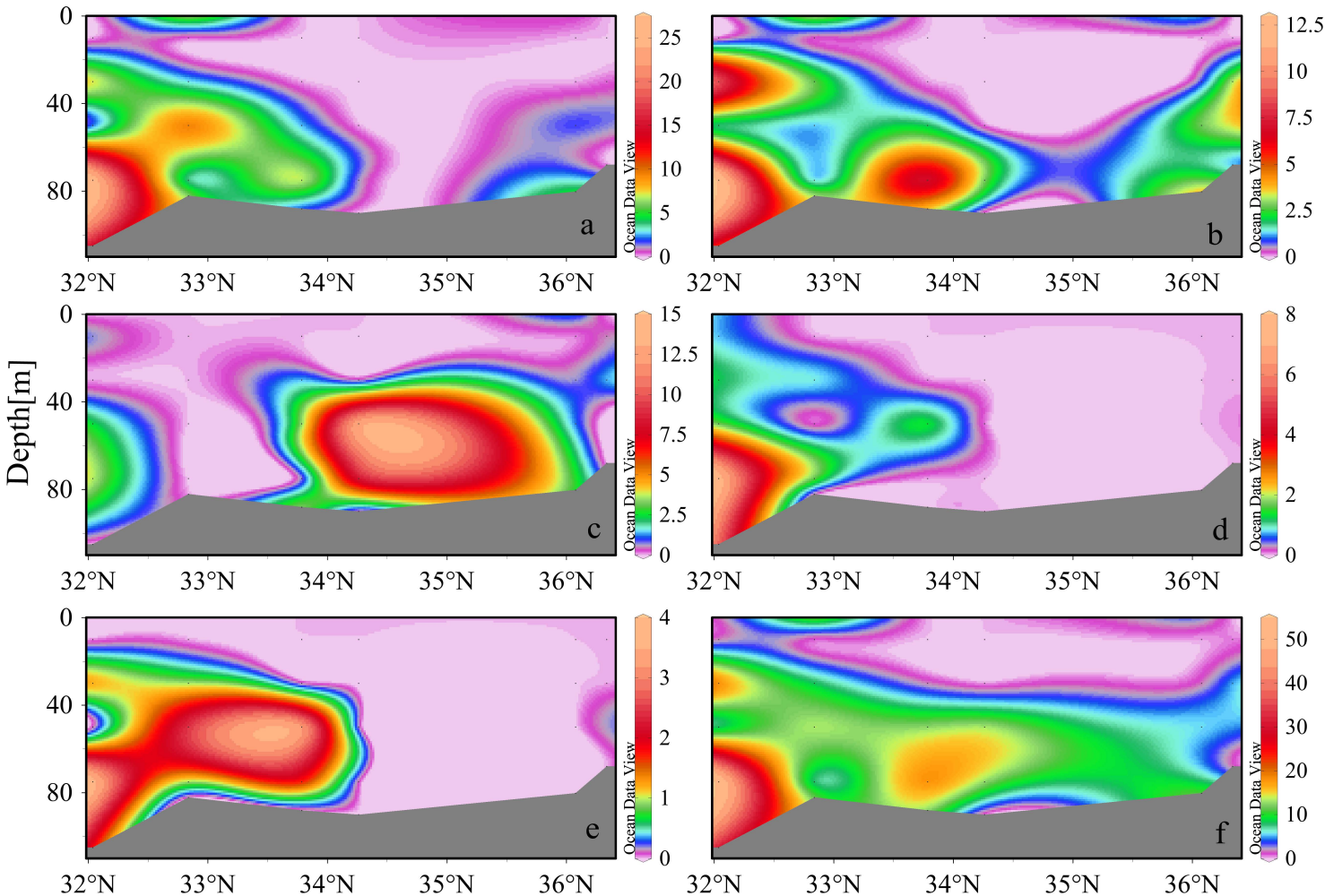

Fig. 10a. Vertical distribution of the coccosphere abundance along section A in summer (unit: coccoliths $\mathrm{mL}^{-1}$ ). (a) Gephyrocapsa oceanica; (b) Emiliania huxleyi; (c) Algirosphaera robusta; (d) Helicosphaera carteri; (e) Calcidiscus leptoporus; and (f) sum.
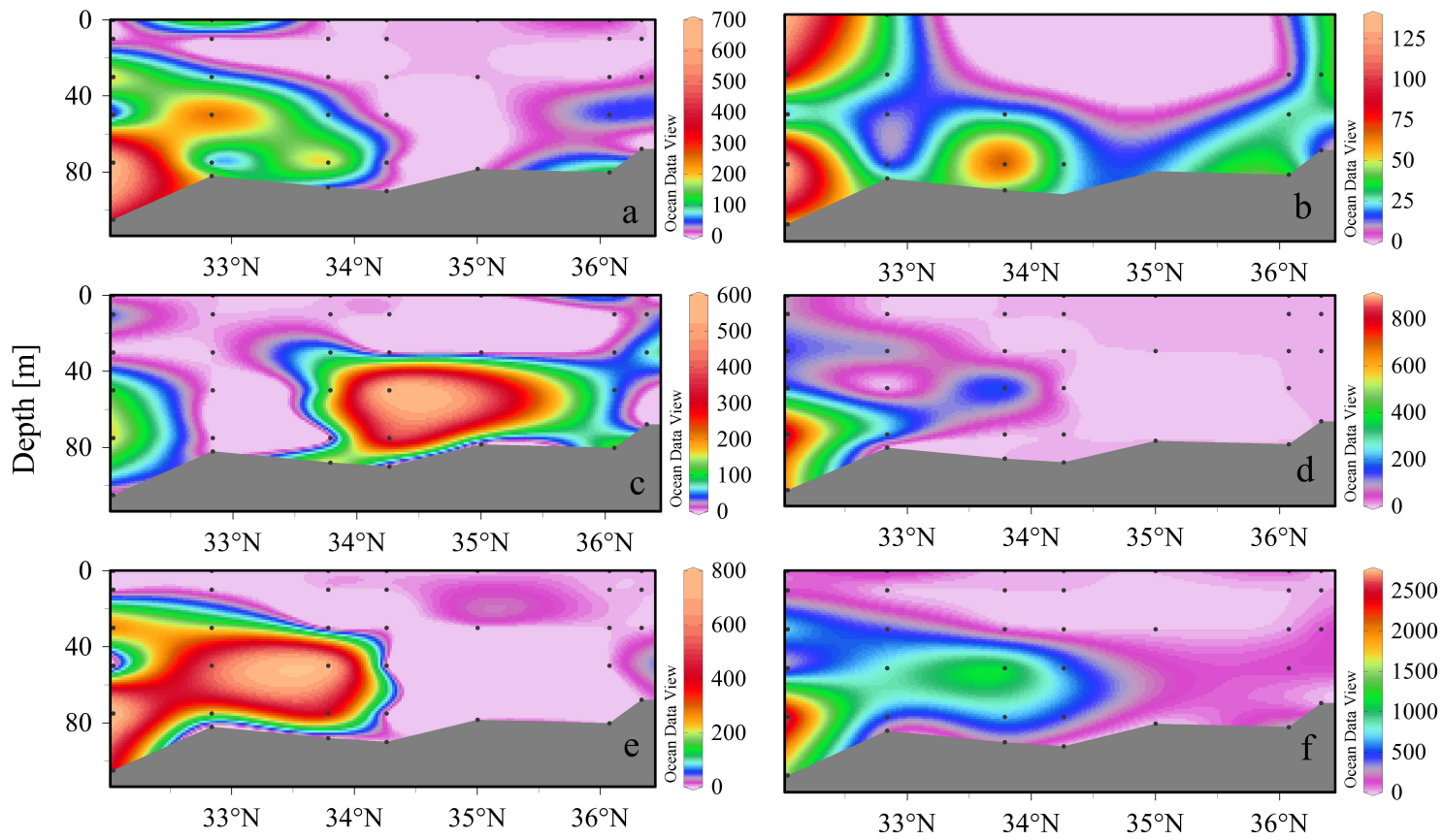

Fig. 10b. Vertical distribution of coccolithophore carbon biomass along section A in summer (unit: ugC $\mathrm{L}^{-1}$ ). (a) Gephyrocapsa oceanica; (b) Emiliania huxleyi; (c) Algirosphaera robusta; (d) Helicosphaera carteri; (e) Calcidiscus leptoporus; and (f) sum. 

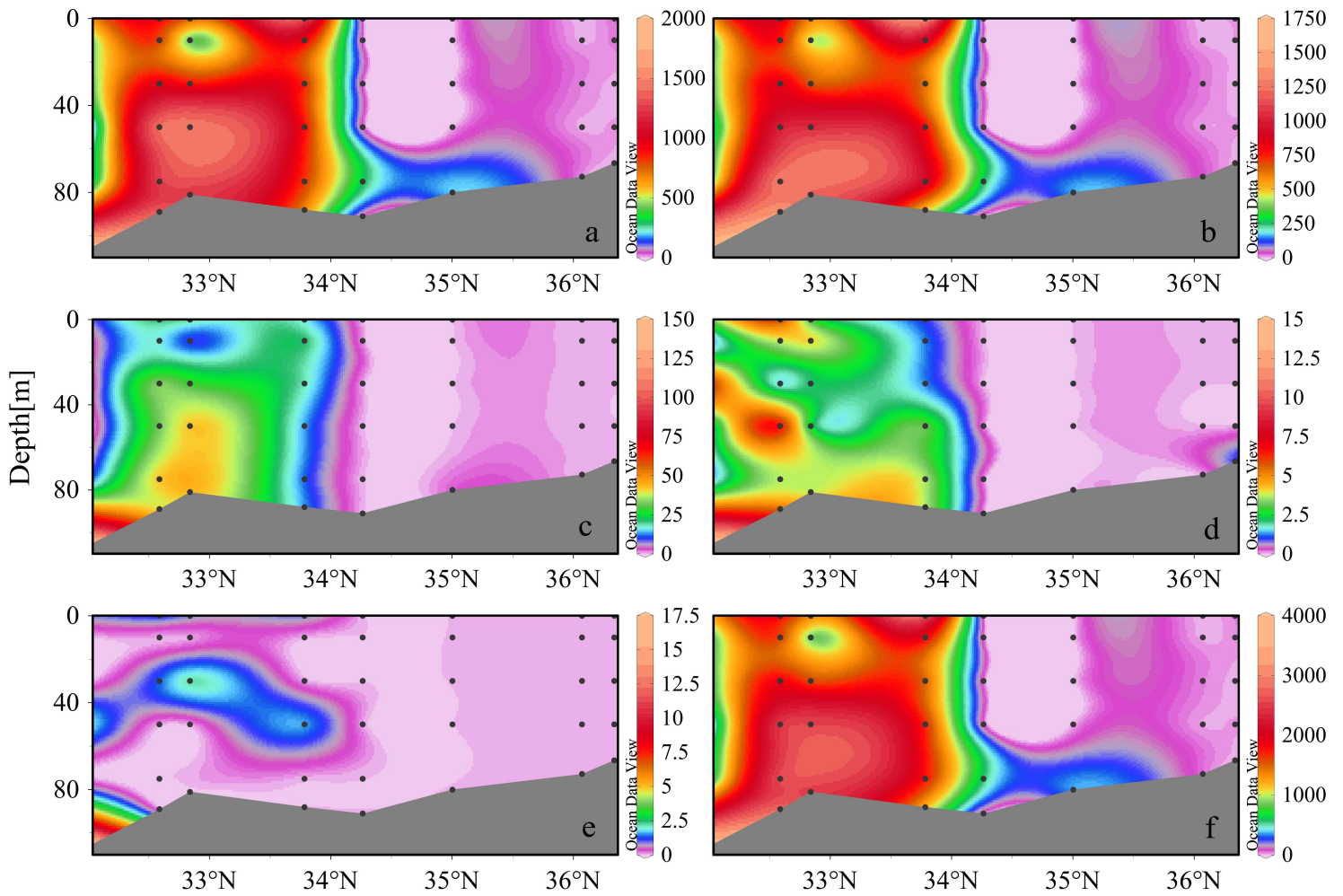

Fig. 11. Vertical distribution of coccolith abundance along section $\mathrm{A}$ in winter (unit: coccoliths $\mathrm{mL}^{-1}$ ). (a) Gephyrocapsa oceanica; (b) Emiliania huxleyi; (c) Helicosphaera carteri; (d) Calcidiscus leptoporus; (e) Braarudosphaera bigelowii; and (f) sum.
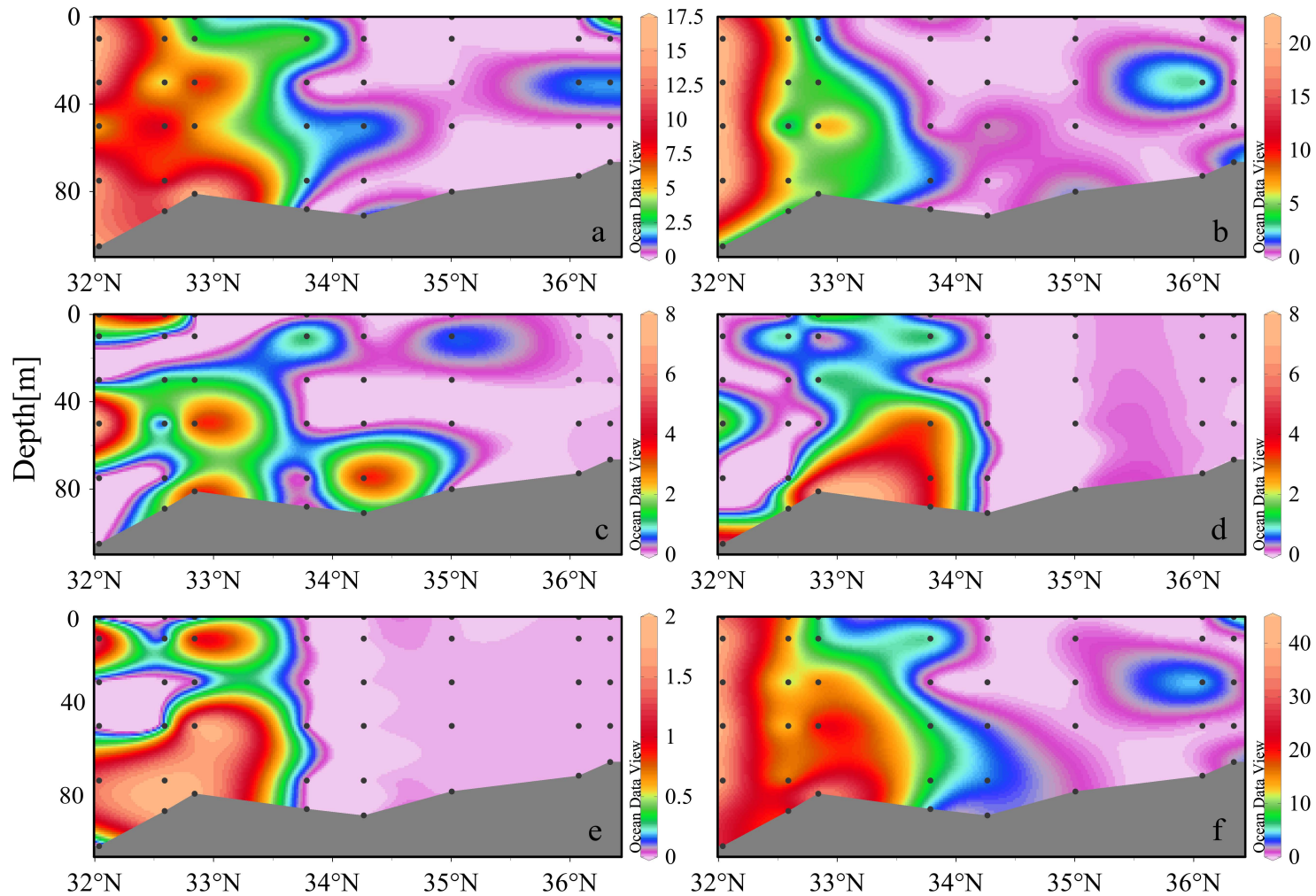

Fig. 12a. Vertical distribution of coccosphere abundance along section $\mathrm{A}$ in winter (unit: coccoliths $\mathrm{mL}^{-1}$ ). (a) Gephyrocapsa oceanica; (b) Emiliania huxleyi; (c) Algirosphaera robusta; (d) Helicosphaera carteri; (e) Calcidiscus leptoporus; and (f) sum. 

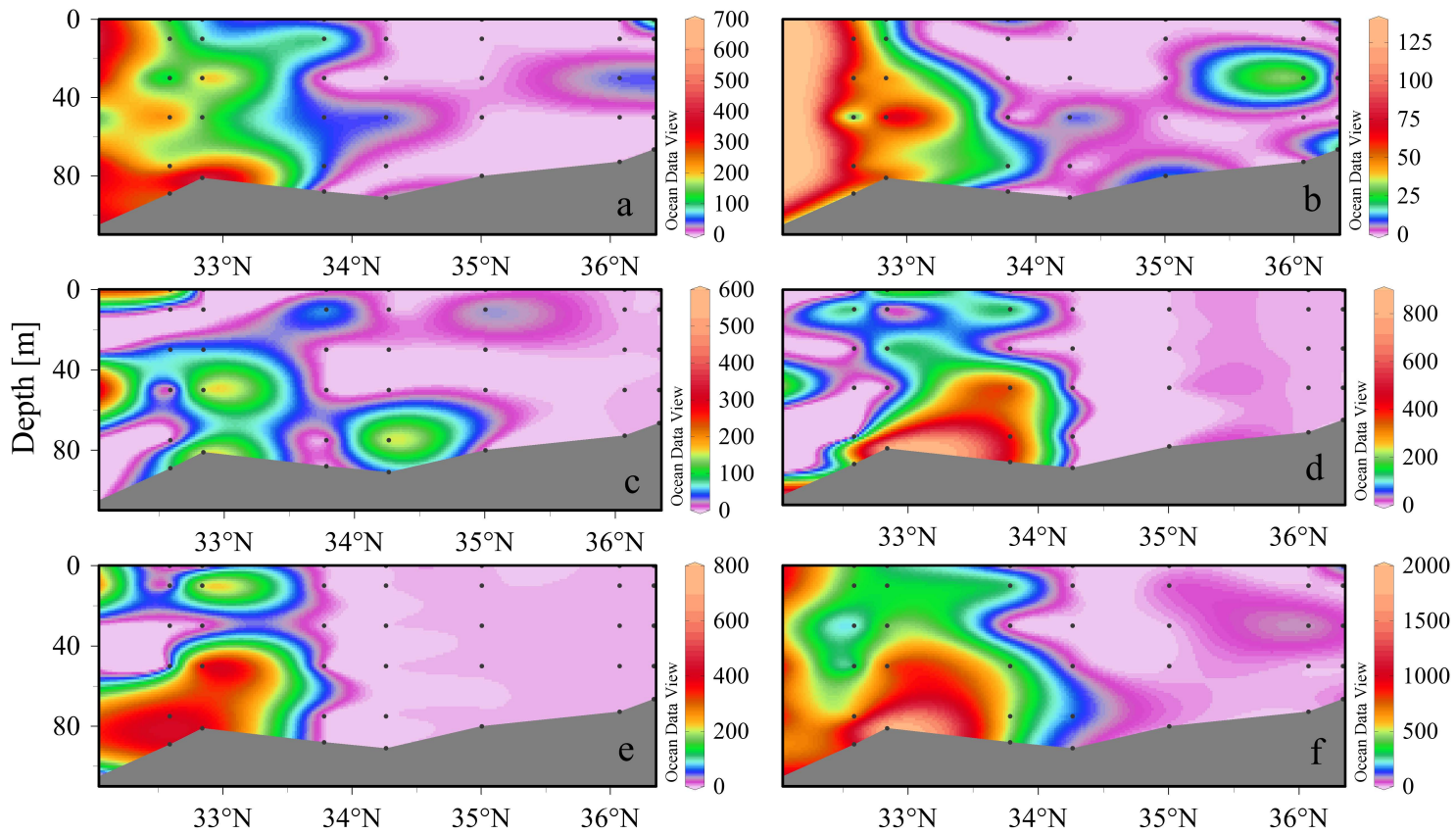

Fig. 12b. Vertical distribution of coccolithophore carbon biomass along section A in winter (unit: ugC $\mathrm{L}^{-1}$ ). (a) Gephyrocapsa oceanica; (b) Emiliania huxleyi; (c) Algirosphaera robusta; (d) Helicosphaera carteri; (e) Calcidiscus leptoporus; and (f) sum.
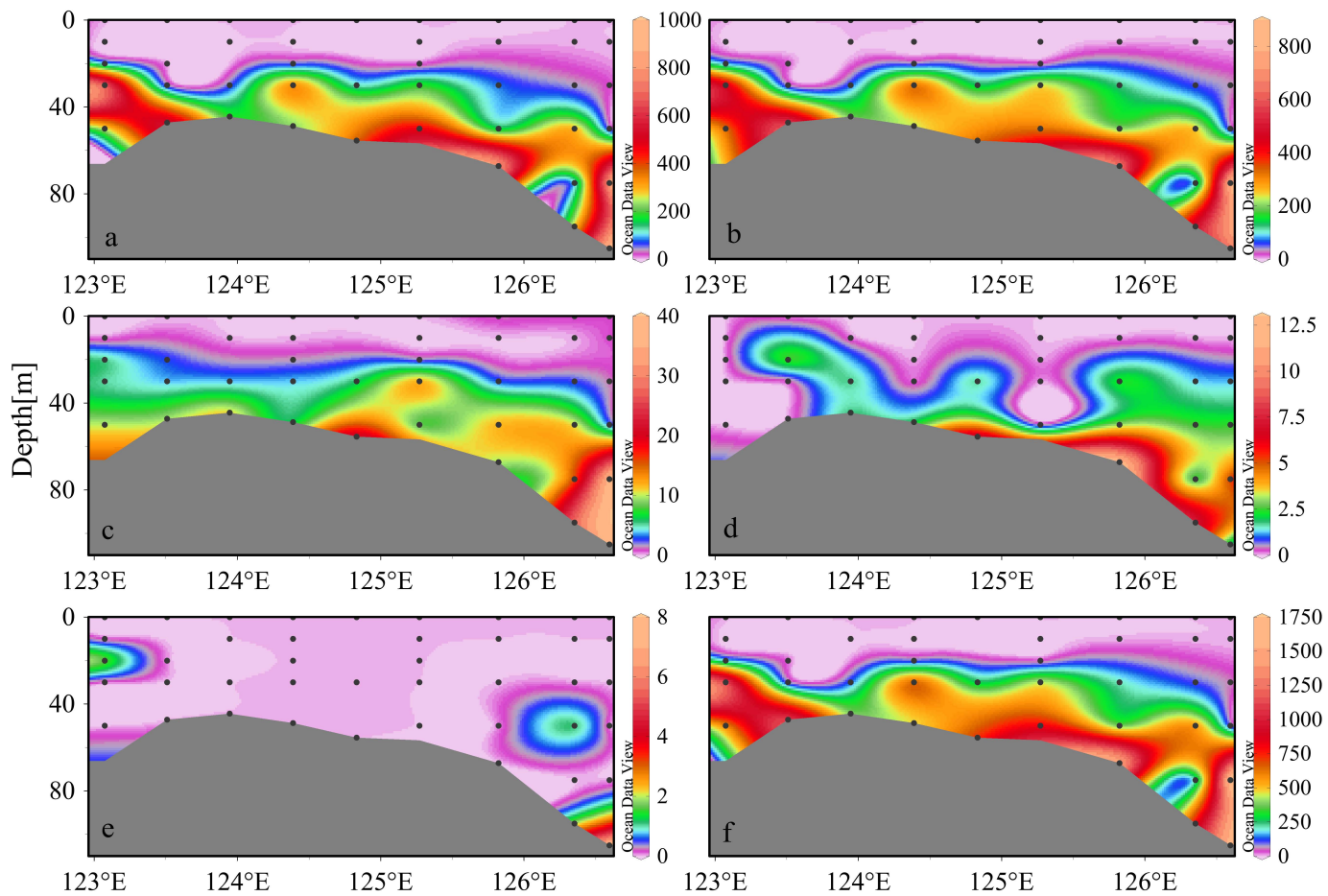

Fig. 13. Vertical distribution of coccolith abundance along section $\mathrm{F}$ in summer (unit: coccoliths $\mathrm{mL}^{-1}$ ). (a) Gephyrocapsa oceanica; (b) Emiliania huxleyi; (c) Helicosphaera carteri; (d) Calcidiscus leptoporus; (e) Braarudosphaera bigelowii; and (f) sum. 

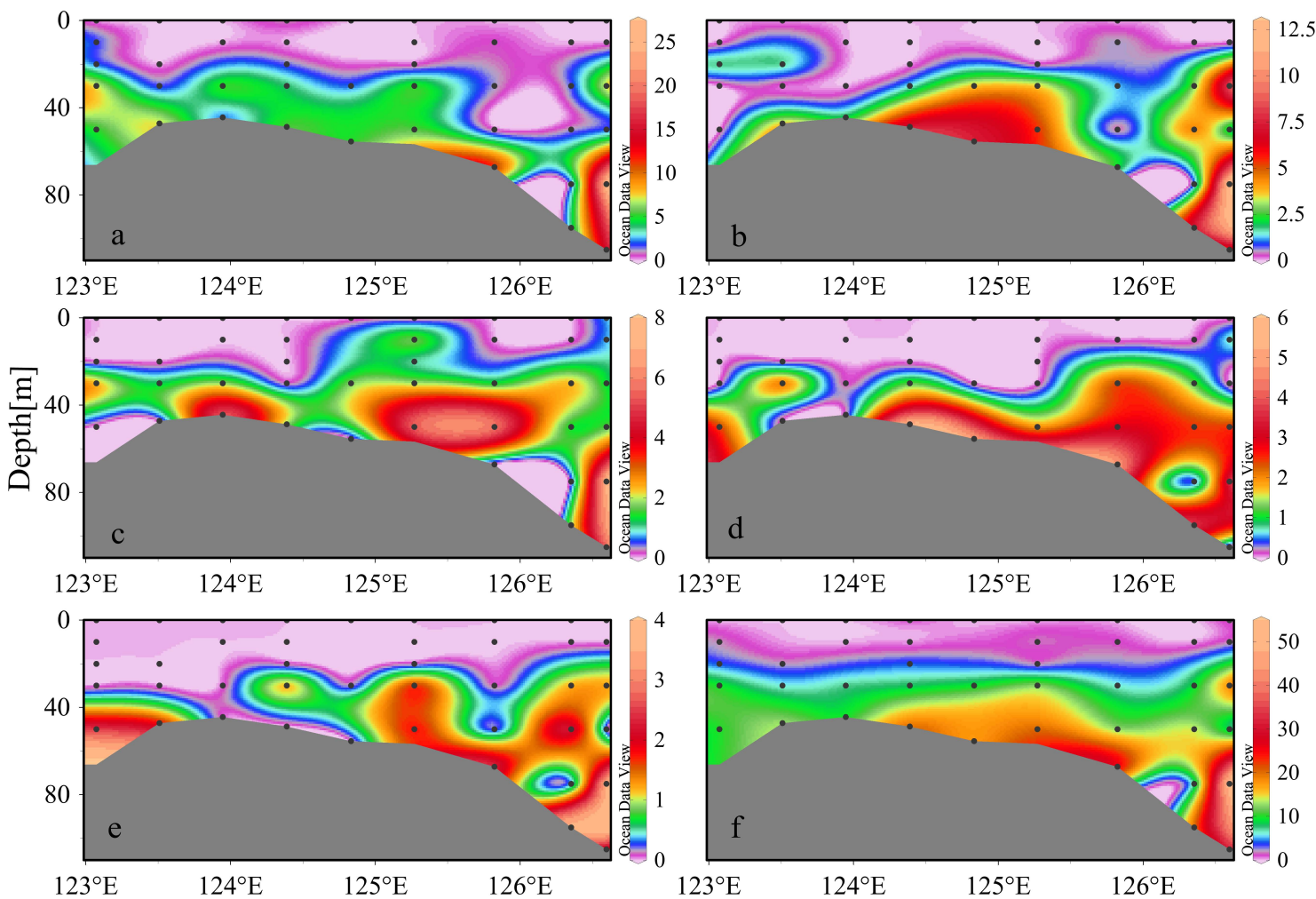

Fig. 14a. Vertical distribution of coccosphere abundance along section $\mathrm{F}$ in summer (unit: coccoliths $\mathrm{mL}^{-1}$ ). (a) Gephyrocapsa oceanica; (b) Emiliania huxleyi; (c) Algirosphaera robusta; (d) Helicosphaera carteri; (e) Calcidiscus leptoporus; and (f) sum.
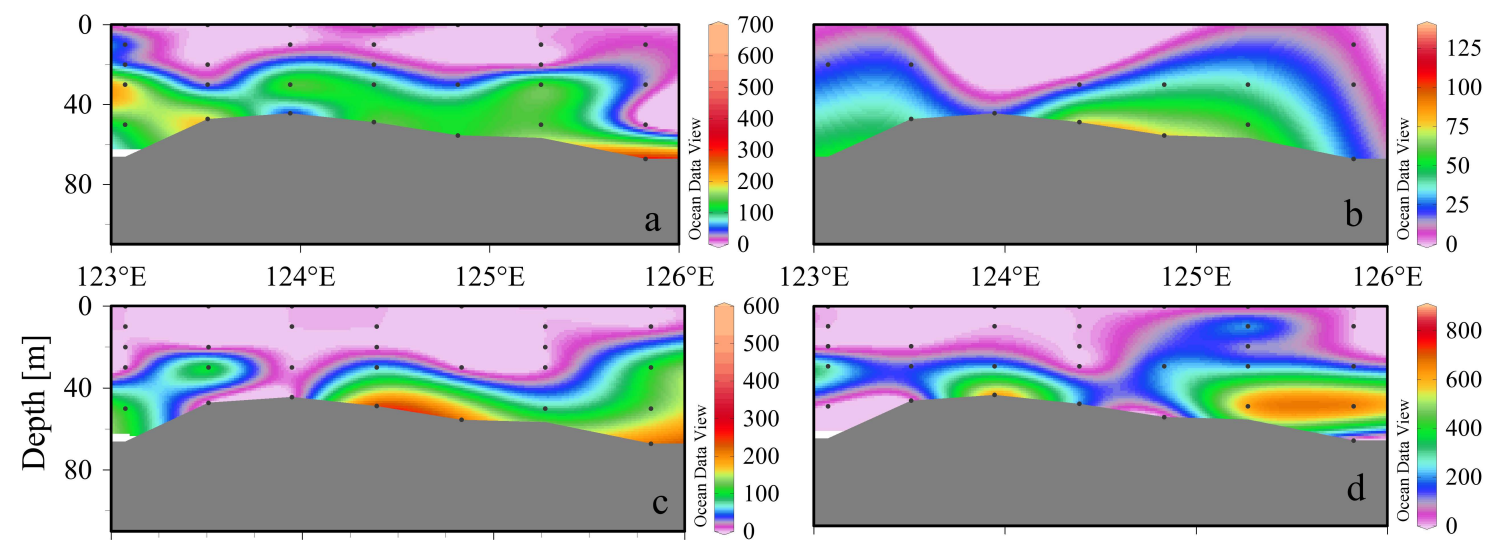

$123^{\circ} \mathrm{E}$

$124^{\circ} \mathrm{E}$

$125^{\circ} \mathrm{E}$

$126^{\circ} \mathrm{E}$
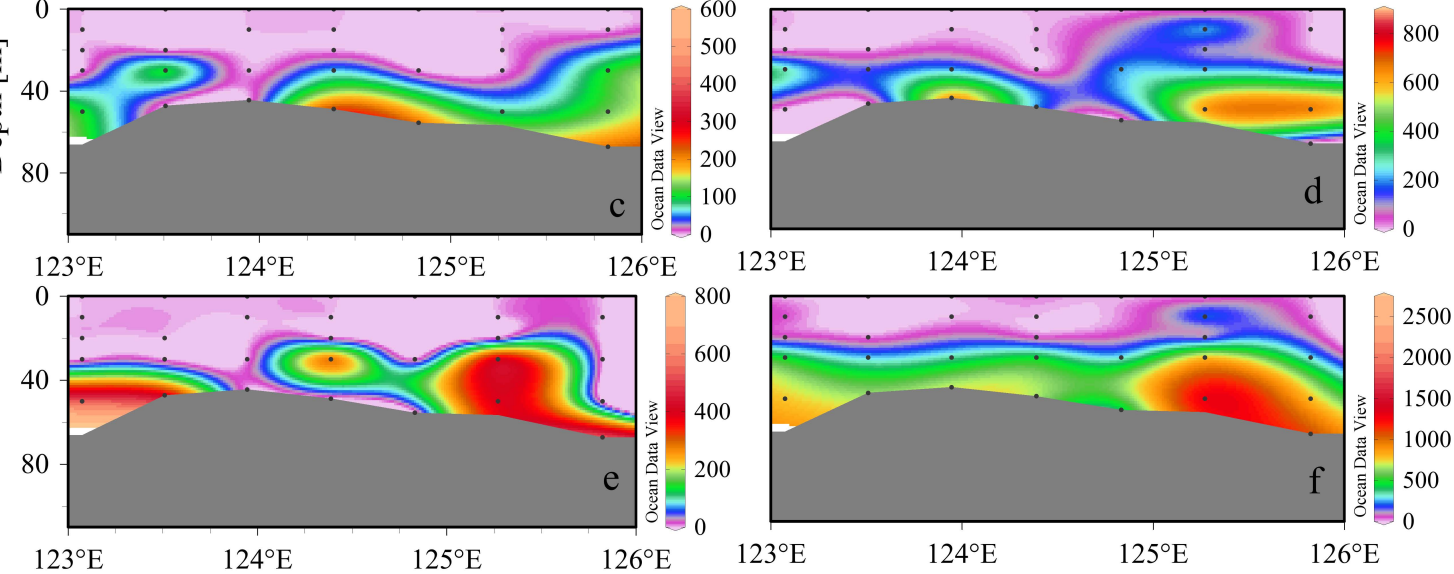

Fig. 14b. Vertical distribution of coccolithophore carbon biomass along section $\mathrm{F}$ in summer (unit: ugC $\mathrm{L}^{-1}$ ). (a) Gephyrocapsa oceanica; (b) Emiliania huxleyi; (c) Algirosphaera robusta; (d) Helicosphaera carteri; (e) Calcidiscus leptoporus; and (f) sum. 

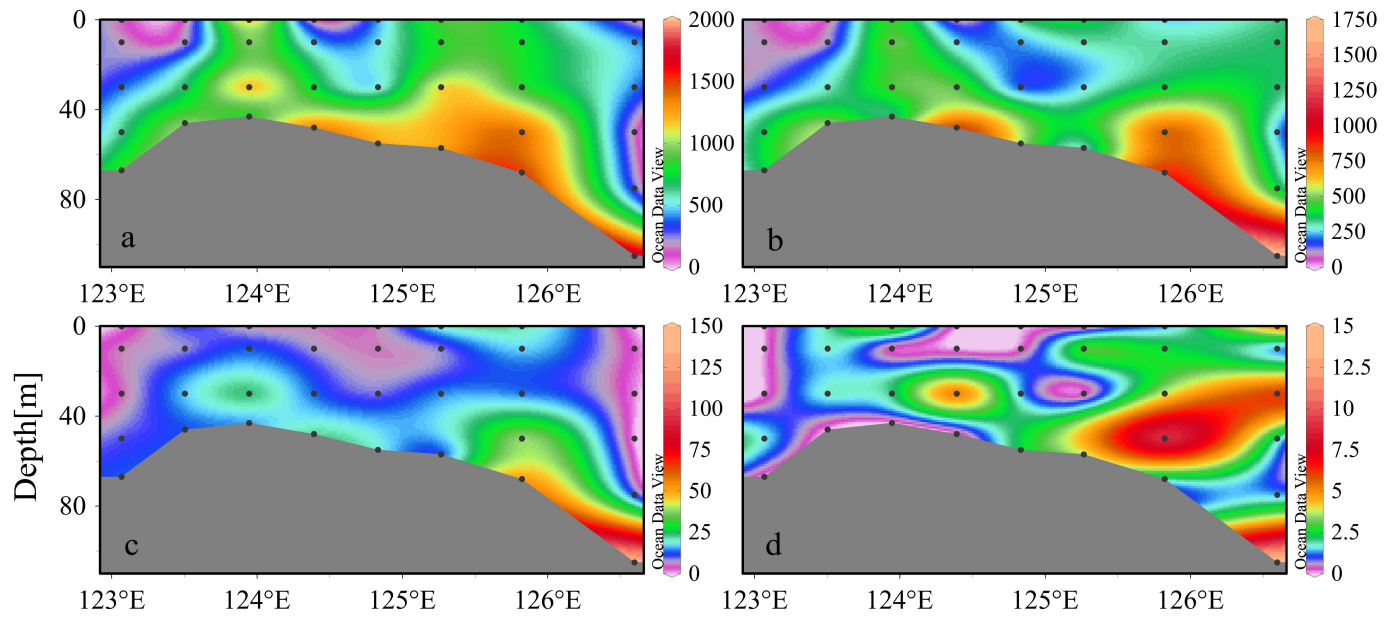

$23^{\circ} \mathrm{E} \quad 124^{\circ} \mathrm{E} \quad 125^{\circ} \mathrm{E} \quad 126^{\circ} \mathrm{E}$
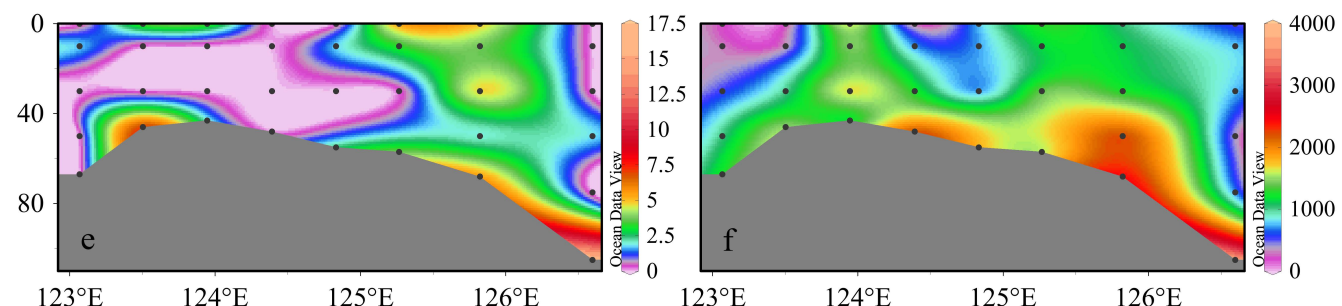

Fig. 15. Vertical distribution of coccolith abundance along section $\mathrm{F}$ in winter (unit: coccoliths $\mathrm{mL}^{-1}$ ). (a) Gephyrocapsa oceanica; (b) Emiliania huxleyi; (c) Helicosphaera carteri; (d) Calcidiscus leptoporus; (e) Braarudosphaera bigelowii; and (f) sum.
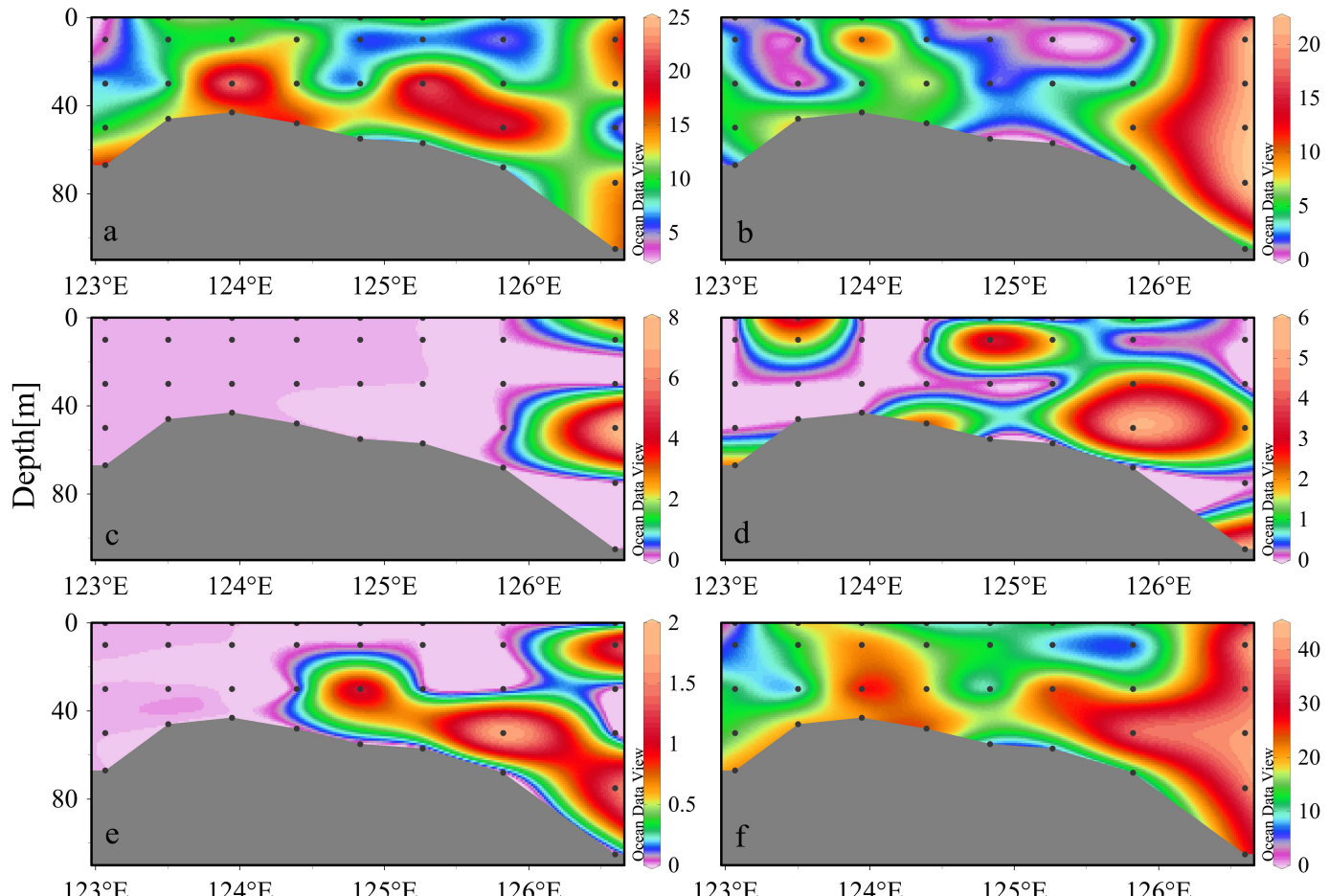

$123^{\circ} \mathrm{E}$

$124^{\circ} \mathrm{E}$

$125^{\circ} \mathrm{E} \quad 126^{\circ} \mathrm{E}$

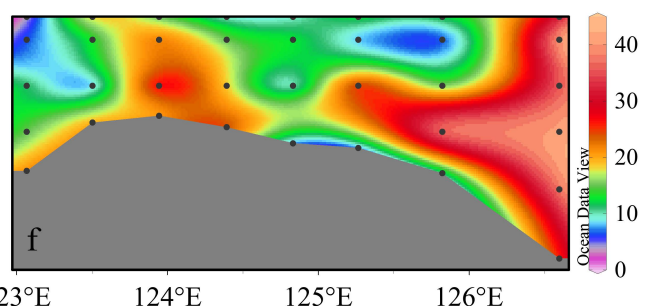

Fig. 16a. Vertical distribution of coccosphere abundance along section $\mathrm{F}$ in winter (unit: coccoliths $\mathrm{mL}^{-1}$ ). (a) Gephyrocapsa oceanica; (b) Emiliania huxleyi; (c) Algirosphaera robusta; (d) Helicosphaera carteri; (e) Calcidiscus leptoporus; and (f) sum. 

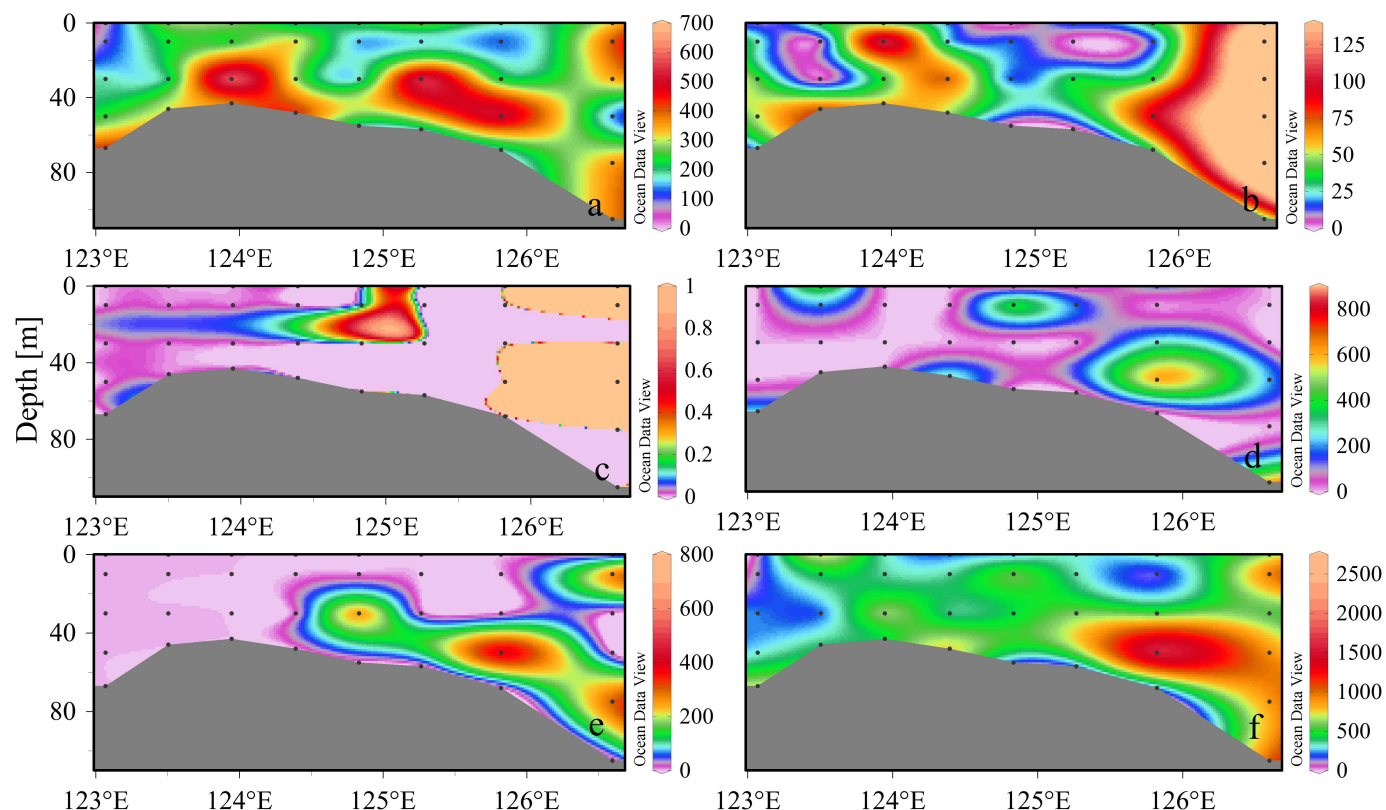

Fig. 16b. Vertical distribution of coccolithophore carbon biomass along section $\mathrm{F}$ in winter (unit: ugC $\mathrm{L}^{-1}$ ). (a) Gephyrocapsa oceanica; (b) Emiliania huxleyi; (c) Algirosphaera robusta; (d) Helicosphaera carteri; (e) Calcidiscus leptoporus; and (f) sum.

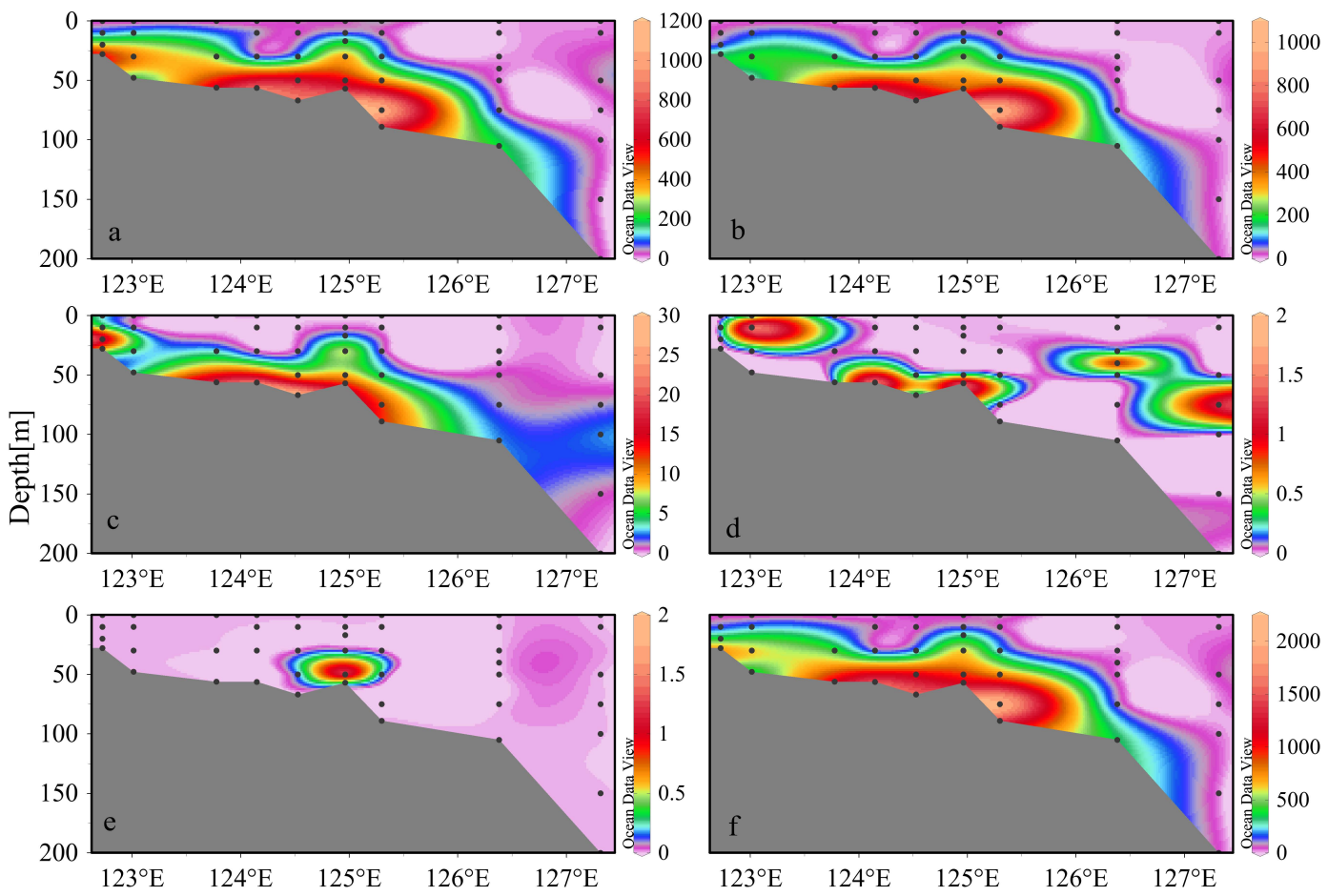

Fig. 17. Vertical distribution of coccolith abundance along section $\mathrm{P}$ in summer (unit: coccoliths $\mathrm{mL}^{-1}$ ). (a) Gephyrocapsa oceanica; (b) Emiliania huxleyi; (c) Helicosphaera carteri; (d) Calcidiscus leptoporus; (e) Braarudosphaera bigelowii; and (f) sum. 

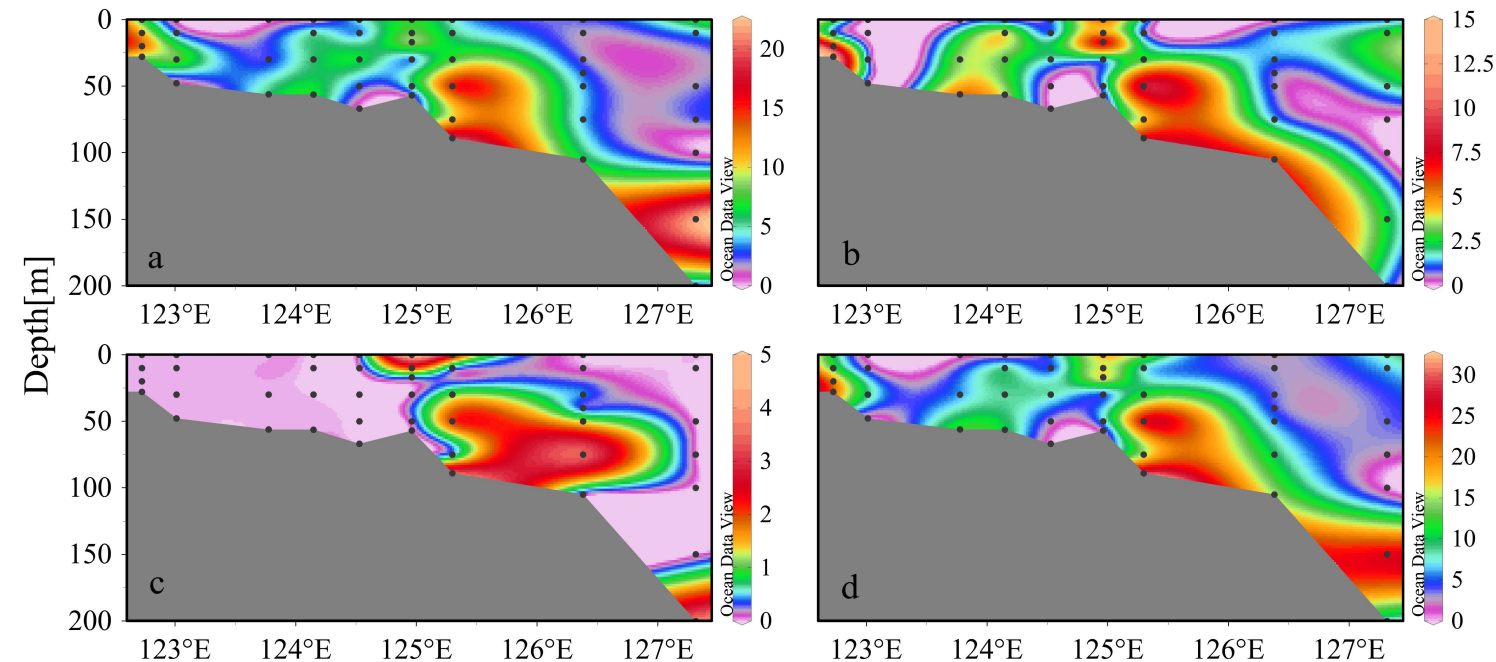

Fig. 18a. Vertical distribution of coccosphere abundance along section $\mathrm{P}$ in summer (unit: coccoliths $\mathrm{mL}^{-1}$ ). (a) Gephyrocapsa oceanica; (b) Emiliania huxleyi; (c) Algirosphaera robusta; and (d) sum.
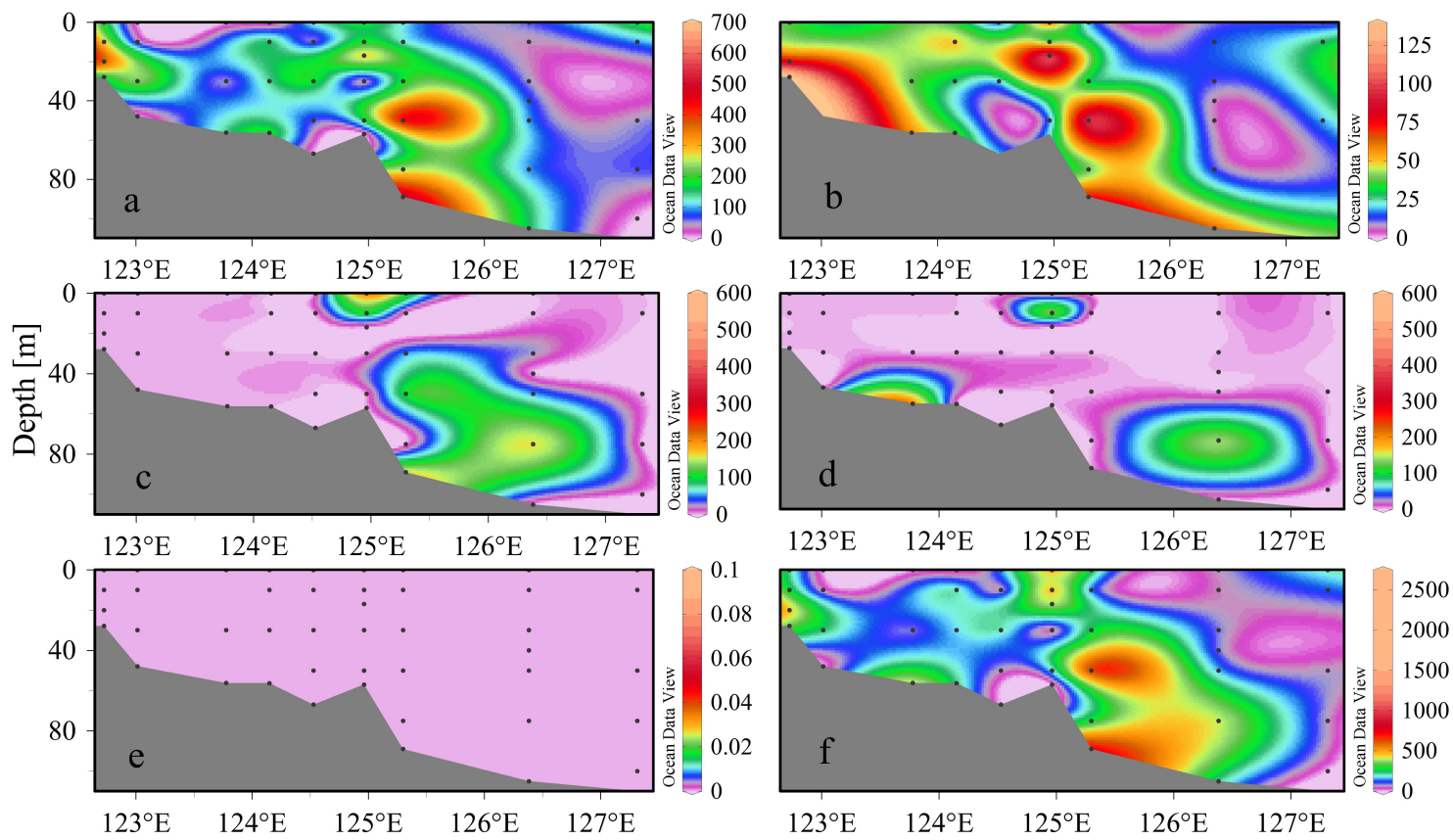

Fig. 18b. Vertical distribution of coccolithophore carbon biomass along section $\mathrm{P}$ in summer (unit: ugC $\mathrm{L}^{-1}$ ). (a) Gephyrocapsa oceanica; (b) Emiliania huxleyi; (c) Algirosphaera robusta; (d) Helicosphaera carteri; (e) Calcidiscus leptoporus; and (f) sum. 
Table 3. Historical data of living coccolithophore assemblage in the Yellow Sea and East China Sea.

\begin{tabular}{|c|c|c|c|c|c|}
\hline $\begin{array}{l}\text { Sampling } \\
\text { time }\end{array}$ & Method & $\begin{array}{l}\text { Dominant } \\
\text { species }\end{array}$ & $\begin{array}{l}\text { Abundance } \\
\left(\text { cells } \mathrm{mL}^{-1}\right)\end{array}$ & Region & Reference \\
\hline $\begin{array}{l}\text { Dec } 2011 \sim \\
\text { Jan } 2012\end{array}$ & $\mathrm{PM}$ & $\begin{array}{l}\text { E. huxleyi, } \\
\text { G. oceanica }\end{array}$ & $0 \sim 40.4$ & $\begin{array}{l}\text { Yellow Sea and East China } \\
\text { Sea (surface) }\end{array}$ & This study \\
\hline Jul 2011 & PM & $\begin{array}{l}\text { E. huxleyi, } \\
\text { G. oceanica }\end{array}$ & $0 \sim 30.6$ & $\begin{array}{l}\text { Yellow Sea and East China } \\
\text { Sea (surface) }\end{array}$ & This study \\
\hline Nov 2010 & PM & $\begin{array}{l}\text { E. huxleyi, } \\
\text { G. oceanica }\end{array}$ & 18.6 & East China Sea & Jin et al. (2013) \\
\hline $\begin{array}{l}\text { Dec } 2009 \sim \\
\text { Feb } 2010\end{array}$ & PM & $\begin{array}{l}\text { E. huxleyi } \\
\text { G. oceanica }\end{array}$ & 3.84 & $\begin{array}{l}\text { Yellow Sea and East } \\
\text { China Sea }\end{array}$ & Zhang (2011) \\
\hline Jul Sep 2009 & $\mathrm{PM}$ & $\begin{array}{l}\text { E. huxleyi } \\
\text { G. oceanica }\end{array}$ & 2.84 & $\begin{array}{l}\text { Yellow Sea and East } \\
\text { China Sea }\end{array}$ & Zhang (2011) \\
\hline Jul Aug 2009 & SEM/PM & $\begin{array}{l}\text { E. huxleyi } \\
\text { G. oceanica }\end{array}$ & 8.41 & $\begin{array}{l}\text { Yellow Sea and East } \\
\text { China Sea }\end{array}$ & Luan (2010) \\
\hline Dec 1997 & SEM & $\begin{array}{l}\text { E. huxleyi, } \\
\text { G. oceanica }\end{array}$ & $0 \sim 56.4$ & $\begin{array}{l}\text { East China Sea } \\
\text { (surface) }\end{array}$ & Yang et al. (2004) \\
\hline Jul 1996 & SEM & Uncertain* & $11.5 \sim 19.7$ & $\begin{array}{l}\text { Northwest Taiwan } \\
\text { (surface) }\end{array}$ & Yang et al. (2001) \\
\hline Apr 1996 & HPLC & Unclear & - & PN Section & Furaya et al. (2003) \\
\hline Jul Aug 1994 & HPLC & Unclear & - & PN Section & Furaya et al. (2003) \\
\hline Jan $\sim$ Mar 1993 & IM/SEM & $\begin{array}{l}\text { E. huxleyi, } \\
\text { G. oceanica }\end{array}$ & - & PN Section & Furaya et al. (1996) \\
\hline Jul 1992 & SEM & $\begin{array}{l}\text { E. huxleyi, } \\
\text { G. oceanica }\end{array}$ & $0 \sim 64.5$ & $\begin{array}{l}\text { East China Sea } \\
\text { (surface) }\end{array}$ & Yang et al. (2004) \\
\hline Aug 1981 & SEM/PM & $\begin{array}{l}\text { E. huxleyi, } \\
\text { G. oceanica }\end{array}$ & - & PN Section & Wang et al. (1988) \\
\hline $\begin{array}{l}\text { Oct } \sim \text { Dec } \\
1969\end{array}$ & $\mathrm{PM}$ & Unclear & - & $\begin{array}{l}\text { Two stations in East } \\
\text { China Sea }\end{array}$ & Okada et al. (1975) \\
\hline
\end{tabular}

IM: Inverted microscope; PM: Polarized microscope; SEM: Scanning electron microscope; HPLC: High-performance liquid chromatography. ${ }^{*}$ Uncertain dominant species at different stations.

and 10.92 cells $\mathrm{mL}^{-1}$, respectively. The abundance of coccoliths was relatively higher inshore and declined suddenly towards offshore (Fig. 21). Gephyrocapsa oceanica was the absolutely dominating species, with the abundance ranging from 0 to 1729.09 coccoliths $\mathrm{mL}^{-1}$, and the average value was 131.04 coccoliths $\mathrm{mL}^{-1}$. The abundance distribution of coccosphere cells was mainly determined by the distribution of Gephyrocapsa oceanica, similar to coccoliths. High Helicosphaera carteri coccosphere cell abundance was found offshore (Fig. 22a). The highest coccolithophore carbon biomass concentration along section $\mathrm{E}$ was observed in the sub-surface layer (30-50 m, up to $\left.984 \mu g \mathrm{gL}^{-1}\right)$ inshore, mostly contributed by the dominant species Geophyrocapsa oceanica (Fig. 22b). Another high carbon biomass region was found in the same layer offshore between $125^{\circ} \mathrm{E}$ and $126^{\circ} \mathrm{E}$, mainly contributed by Helicosphaera carteri and Calcidiscus leptoporus (Fig. 22b).

In winter, the abundance of coccoliths and cells ranged $\quad 7.35 \sim 1413.04$ coccoliths $\mathrm{mL}^{-1}$ and $1.05 \sim$ 71.66 cells $\mathrm{mL}^{-1}$, with an average of 422.77 coccoliths $\mathrm{mL}^{-1}$ and 22.50 cells $\mathrm{mL}^{-1}$, respectively. The abundance of coccoliths was relatively higher inshore throughout the water column and in the bottom layer offshore right above the continental shelf (Fig. 23). Gephyrocapsa oceanica and Emiliania huxleyi were two dominating species, with the abundance ranging from $5.25 \sim 1029.00$ coccoliths $\mathrm{mL}^{-1}$ and $2.1 \sim 679.88$ coccoliths $\mathrm{mL}^{-1}$, with the average values of 206.28 coccoliths $\mathrm{mL}^{-1}$ and 212.87 coccoliths $\mathrm{mL}^{-1}$ respectively. Braarudosphaera bigelowii coccolith was only found in the surface layer above the edge of the continental shelf. However, the Braarudosphaera bigelowii coccosphere 

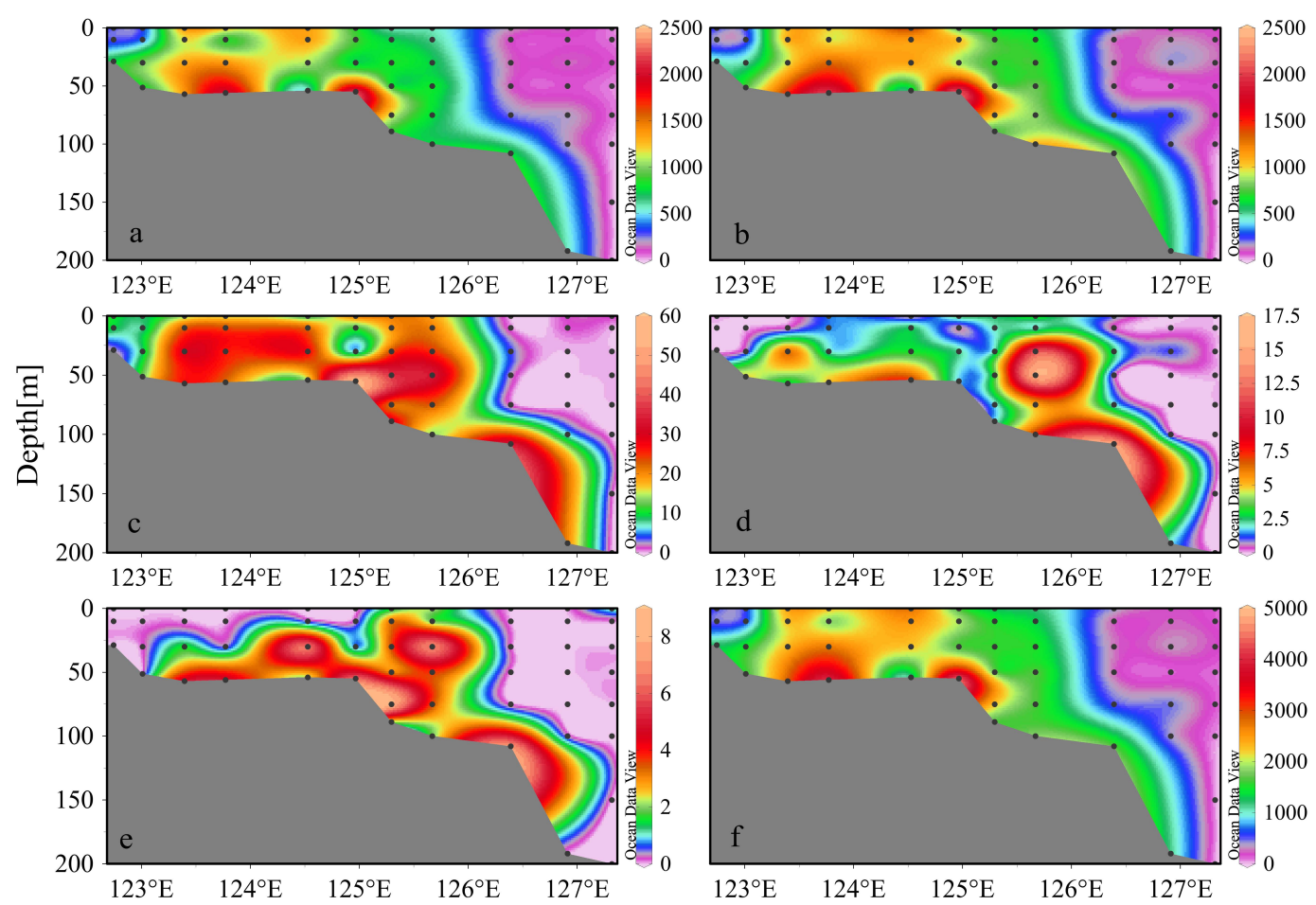

Fig. 19. Vertical distribution of coccolithophore carbon biomass along section $\mathrm{P}$ in winter (unit: $\mathrm{ugC}^{-1}$ ). (a) Gephyrocapsa oceanica; (b) Emiliania huxleyi; (c) Algirosphaera robusta; (d) Helicosphaera carteri; (e) Calcidiscus leptoporus; and (f) sum.
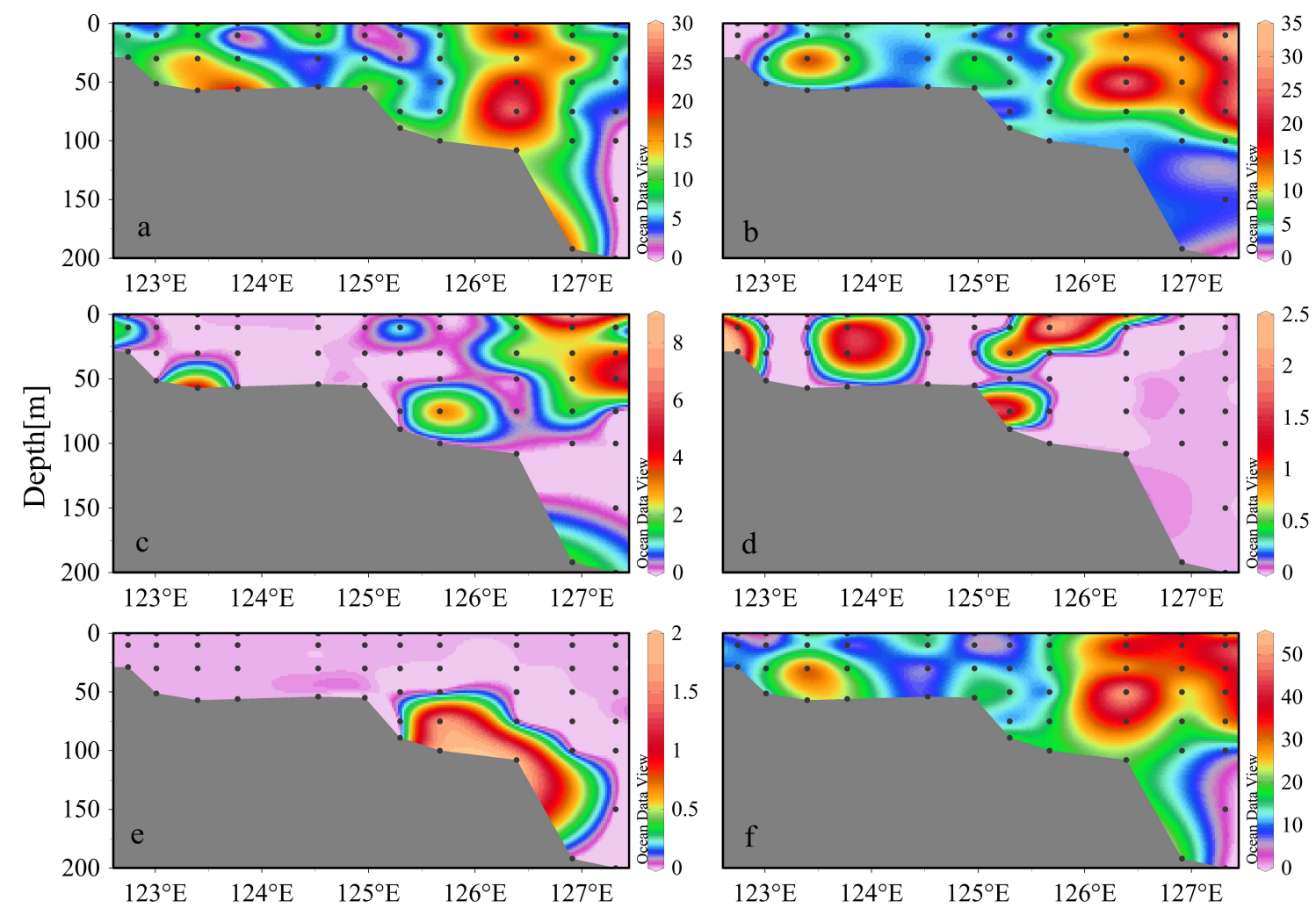

Fig. 20a. Vertical distribution of coccosphere abundance along section $\mathrm{P}$ in winter (unit: coccoliths $\mathrm{mL}^{-1}$ ). (a) Gephyrocapsa oceanica; (b) Emiliania huxleyi; (c) Algirosphaera robusta; (d) Helicosphaera carteri; (e) Calcidiscus leptoporus; and (f) sum. 
cells were mainly observed in the layer from $60 \sim 80 \mathrm{~m}$. High Helicosphaera carteri coccosphere cell abundance was found inshore, and other species were mainly observed offshore. The Gephyrocapsa oceanica and Emiliania huxleyi coccosphere cell distributions mainly determined the distribution of summed cell abundance (Fig. 24a), whereas the calculated total coccolithophore carbon biomass was mostly contributed by Helicosphaera carteri nearshore, showing the highest value and contributed by Gephyrocapsa oceanica and Calcidiscus leptoporus towards offshore (Fig. 24b).

\section{Discussion and Conclusion}

In the current study on coccolithophore and coccolith distribution in the Yellow Sea and the East China Sea, Gephyrocapsa oceanica and Emiliania huxleyi were the two major dominant species, consistent with the previous studies shown in Table 2.

In summer, in the coccolith CCA diagram (Fig. 25), axis 1 mainly related to sampling depth and temperature while axis 2 mainly related to ammonium concentration. As shown in Fig. 13, Gephyrocapsa oceanica, a tropical or warm water coccolithophore species, and Emiliania huxleyi, an eurythermal species (Okada, 1971; Paasche, 2001), both related to different environmental factors in the same degree, indicating that they are able to survive in various environmental conditions. Therefore, these two species have absolute advantages in the Yellow Sea and East China Sea. Similarly, Helicosphaera carteri, with a high frequency, widely survives in the survey area, whereas Calcidiscus leptoporus tends to occur in cool waters and nutrient-rich environments. Differently, Syracosphaera spp. prefers cool waters and rather oligotrophic conditions. Umbilicosphaera sibogae had obvious positive correlation with sampling depth. In the coccosphere CCA diagram (Fig. 26), axis 1 related to sampling depth and temperature, while axis 2 related to nitrate concentration. The correlation between the main species and the environmental factors were similar to those of the coccolith for the dominant species, Gephyrocapsa oceanica and Emiliania huxleyi. However, Syracosphaera spp., Helicosphaera carteri, Calcidiscus leptoporus and Umbilicosphaera sibogae had obvious positive correlation with sampling depth.

In the coccolith CCA diagram of winter sampling (Fig. 27), axis 1 mainly related to nitrate concentration and temperature, while axis 2 mainly related to sampling depth and phosphate concentration. Similar to that in summer, Gephyrocapsa oceanica, Emiliania huxleyi and Helicosphaera carteri, with a high frequency, widely survive in the survey area, while Braarudosphaera bigelowii tends to occur in rather oligotrophic conditions. As for the winter coccosphere CCA diagram (Fig. 28), axis 1 related to salinity, temperature and phosphate concentration, while axis 2 related to sampling depth and ammonium concentration. Gephyrocapsa oceanica, Emiliania huxleyi and Calcidiscus leptoporus related to most of the environmental factors in the same degree, while Helicosphaera carteri showed obvious positive correlation with phosphate concentration.

Okada and Honjo (1975) reported that the distribution of LCs associated with nutrient concentrations, especially nitrate. Winter et al. (2002) found a higher abundance of LCs in the surface layer, above the nitrate halocline and in the photic zone under the DCM (deep chlorophyll maximum) in the Caribbean Sea. Andruleit et al. (2003) believed that the mixing layer depth was the decisive factor in the abundance of LCs and the competition with diatoms in the northern Arabian Sea; Yang et al. (2004) suggested that the distribution of LCs was mainly affected by temperature and salinity. The study by Mohan et al. (2008) found that the abundance and species of LCs was inversely linked to the silicate concentration in the Indian sector of the Southern Ocean.

In this study, according to Figs. 25 to 28, the distribution of LCs in the Yellow Sea and East China Sea had various connections with temperature and the nutrient concentration. In summer, the abundance of coccolith in the surface layer increased from north to south in the survey area, associated with the environment characteristics. In the Yellow Sea, temperature, salinity and the nutrient concentrations are in general low in summer (Liu and Hu, 2009; Zhang, 2009), which limit the survival and growth of the LCs. As for the East China Sea, the temperature and salinity are both significantly higher (Zou and Xiong, 2001), and the input by the Yangtze River runoff and the Kuroshio waters greatly increased the nutrient concentrations in this area (Wang, 2008). The abundance of coccoliths reaches a high value along section P. The abundance of the coccosphere cells in the survey area presents plaque distribution and is mainly distributed in the Yangtze River diluted water region and the southern part of the East China Sea, resulting from the distribution of temperature, salinity and nutrients in various water masses. Nutrient enrichment is beneficial to the survival and growth of the LCs (Baumann et al., 2005), therefore the maximum abundance of the LCs was found at $20 \mathrm{~m}$ depth where the big phytoplankton blooms took place, consistent with what was observed by Jin and Sun (2013).

In winter, temperature is lower and salinity is higher in the Yellow Sea area, and the particularly low temperature limited the growth of the LCs. In the East China Sea, the Yangtze River runoff increased the nutrient concentrations, and the Kuroshio waters brought high-temperature water mass. As a result, the LC abundance observed in the East China Sea is in general much higher than in the Yellow Sea area. The maximum abundance of the LCs was found in the continental shelf of section P, consistent with the study by Zhang (2011).

In summer, axis 1 is depth dependent (Figs. 25 and 26). Temperature has a strong negative correlation with the depth by linear regression due to stratification effects. In addition to ocean current invasion, the water column depth is the main factor leading to temperature changes. Therefore, the sampling depth as well as the nutrient (mainly nitrate) concen- 

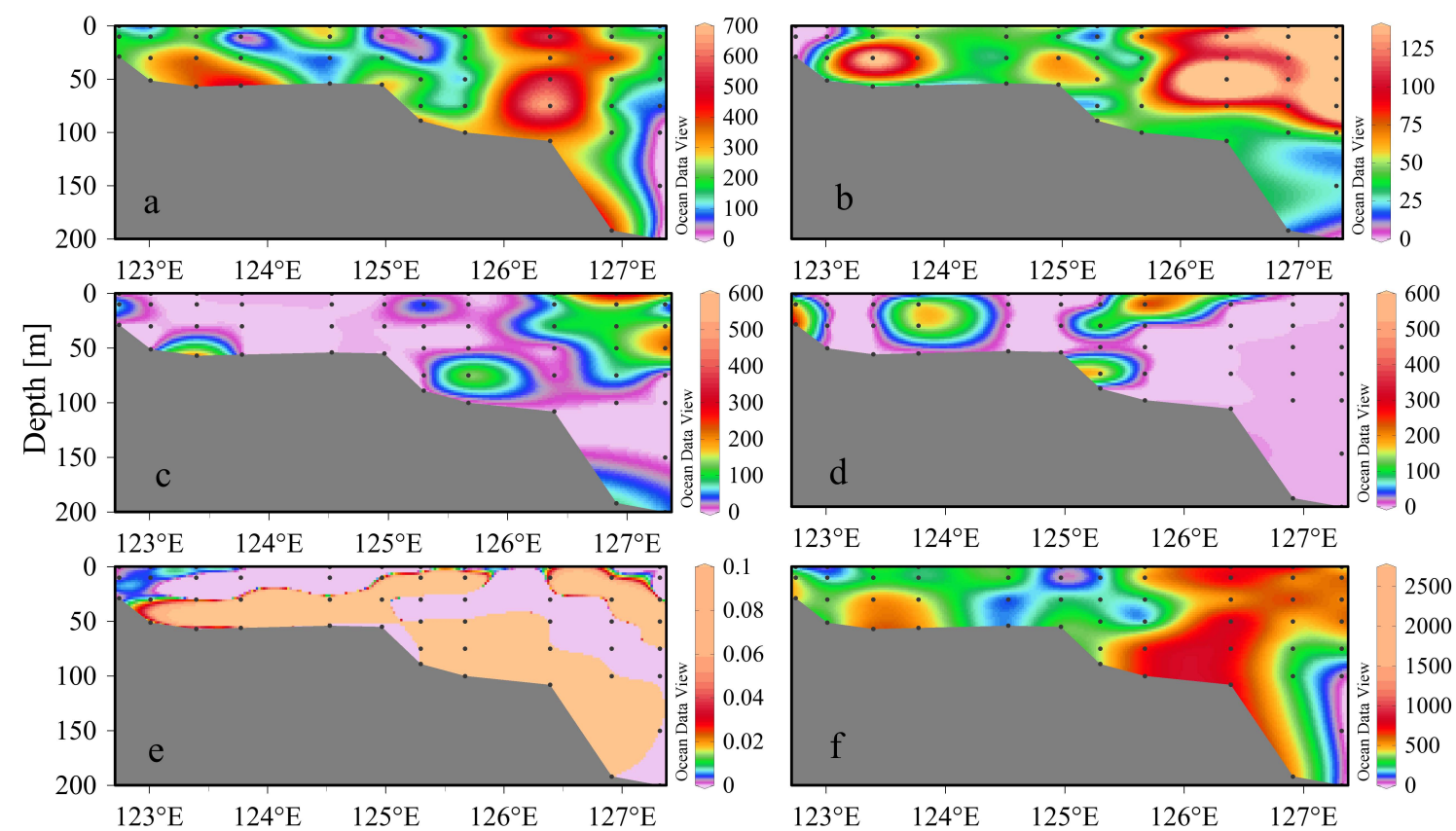

Fig. 20b. Vertical distribution of coccolithophore carbon biomass along section $\mathrm{P}$ in winter (unit: ugC $\mathrm{L}^{-1}$ ). (a) Gephyrocapsa oceanica; (b) Emiliania huxleyi; (c) Algirosphaera robusta; (d) Helicosphaera carteri; (e) Calcidiscus leptoporus; and (f) sum.
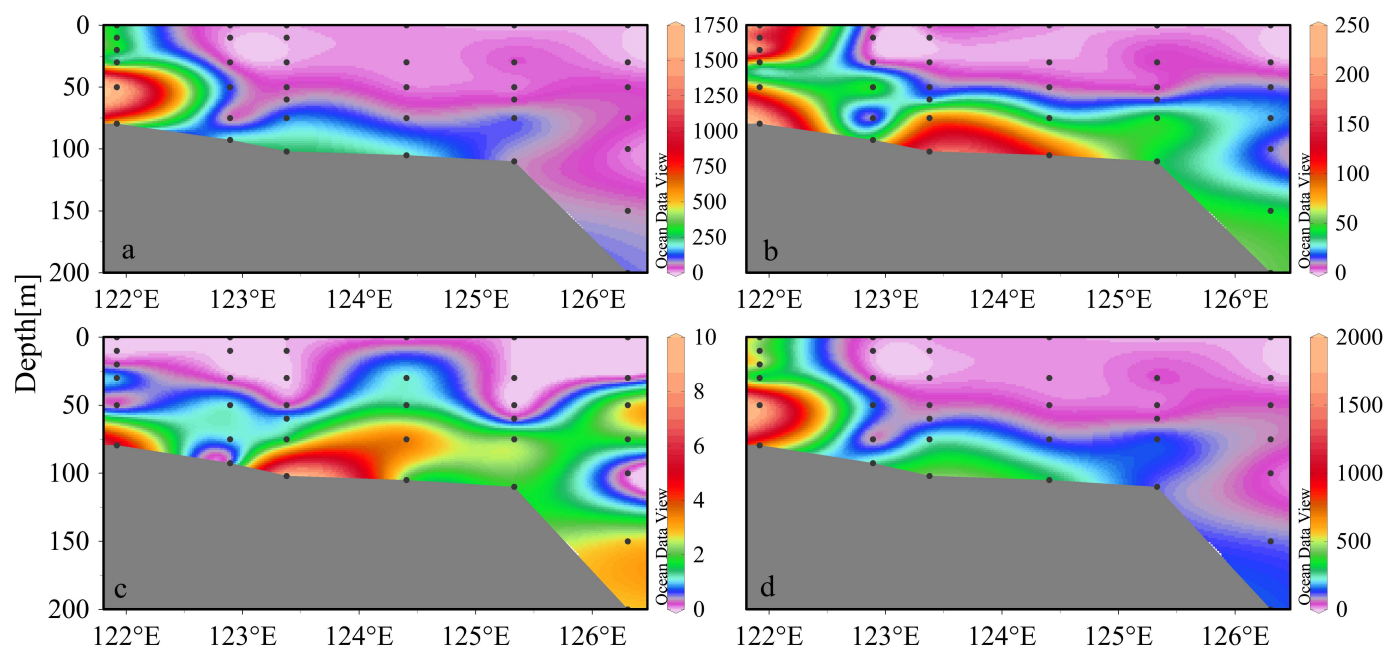

Fig. 21. Vertical distribution of coccolith abundance along section $\mathrm{E}$ in summer (unit: coccoliths $\mathrm{mL}^{-1}$ ). (a) Gephyrocapsa oceanica; (b) Emiliania huxleyi; (c) Helicosphaera carteri; and (d) sum. 

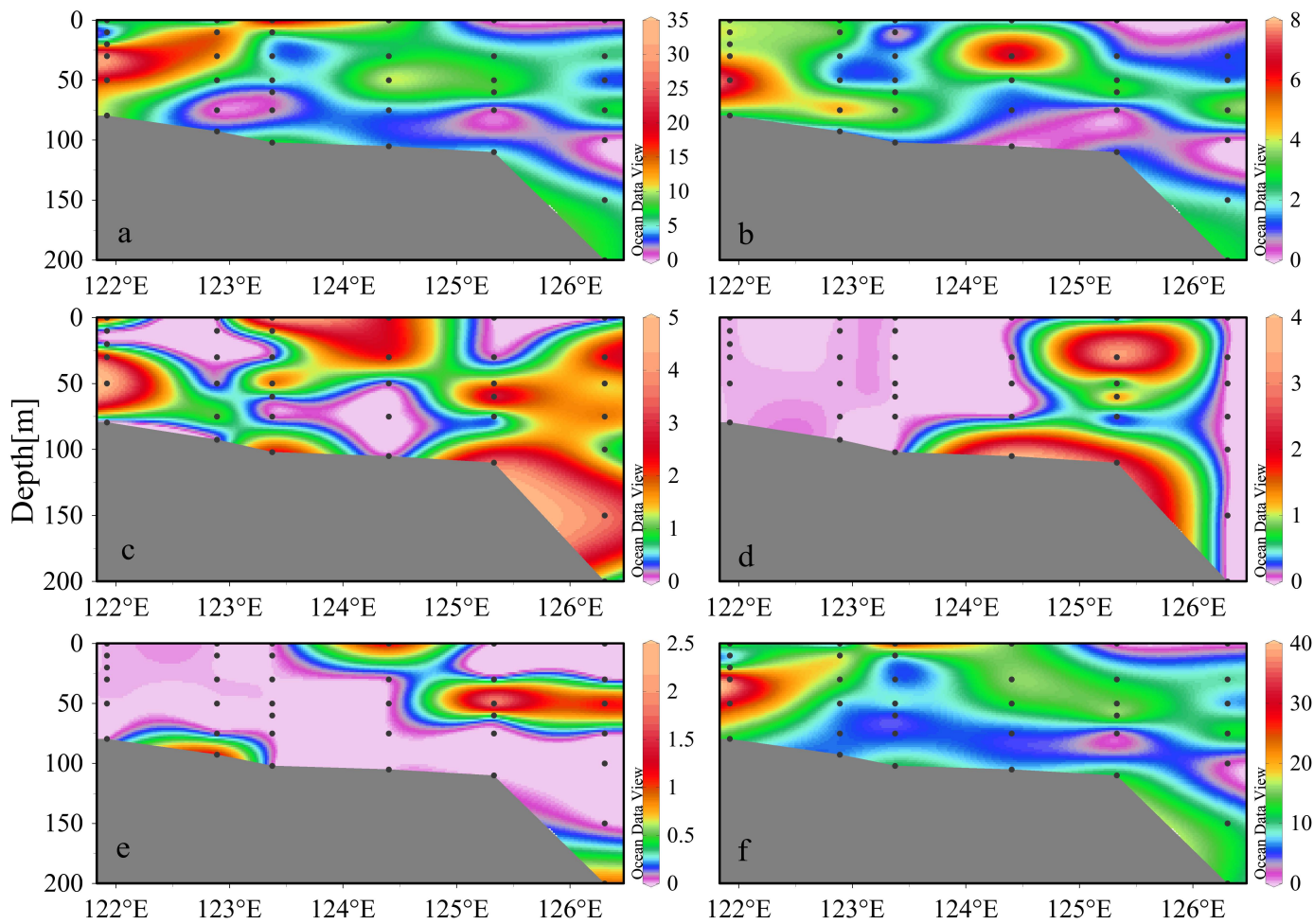

Fig. 22a. Vertical distribution of coccosphere abundance along section $\mathrm{E}$ in summer (unit: coccoliths $\mathrm{mL}^{-1}$ ). (a) Gephyrocapsa oceanica; (b) Emiliania huxleyi; (c) Algirosphaera robusta; (d) Helicosphaera carteri; (e) Calcidiscus leptoporus; and (f) sum.
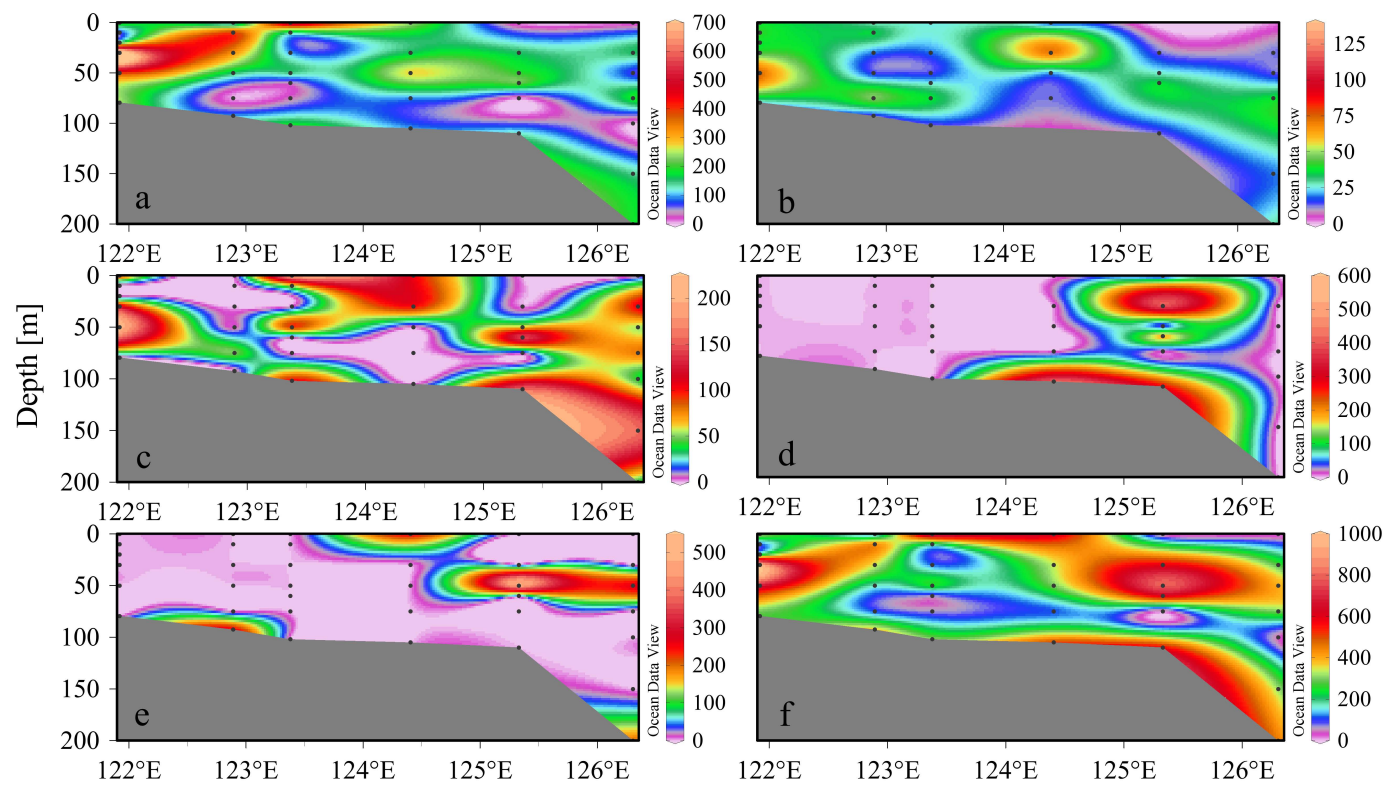

Fig. 22b. Vertical distribution of coccolithophore carbon biomass along section $\mathrm{E}$ in summer (unit: ugC $\mathrm{L}^{-1}$ ). (a) Gephyrocapsa oceanica; (b) Emiliania huxleyi; (c) Algirosphaera robusta; (d) Helicosphaera carteri; (e) Calcidiscus leptoporus; and (f) sum. 

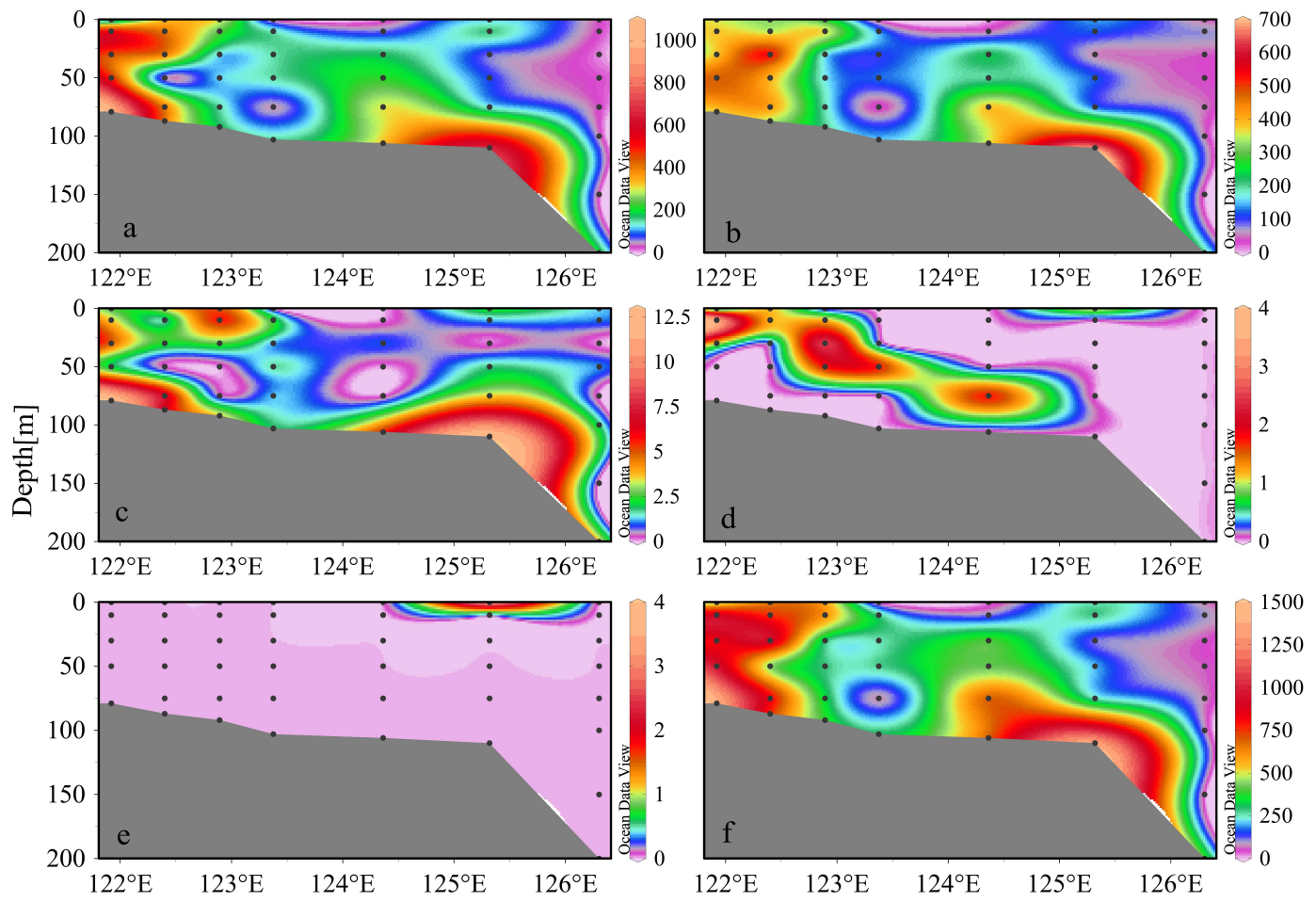

Fig. 23. Vertical distribution of coccolith abundance along section $\mathrm{E}$ in winter (unit: coccoliths $\mathrm{mL}^{-1}$ ). (a) Gephyrocapsa oceanica; (b) Emiliania huxleyi; (c) Helicosphaera carteri; (d) Calcidiscus leptoporus; (e) Braarudosphaera bigelowii; and (f) sum.
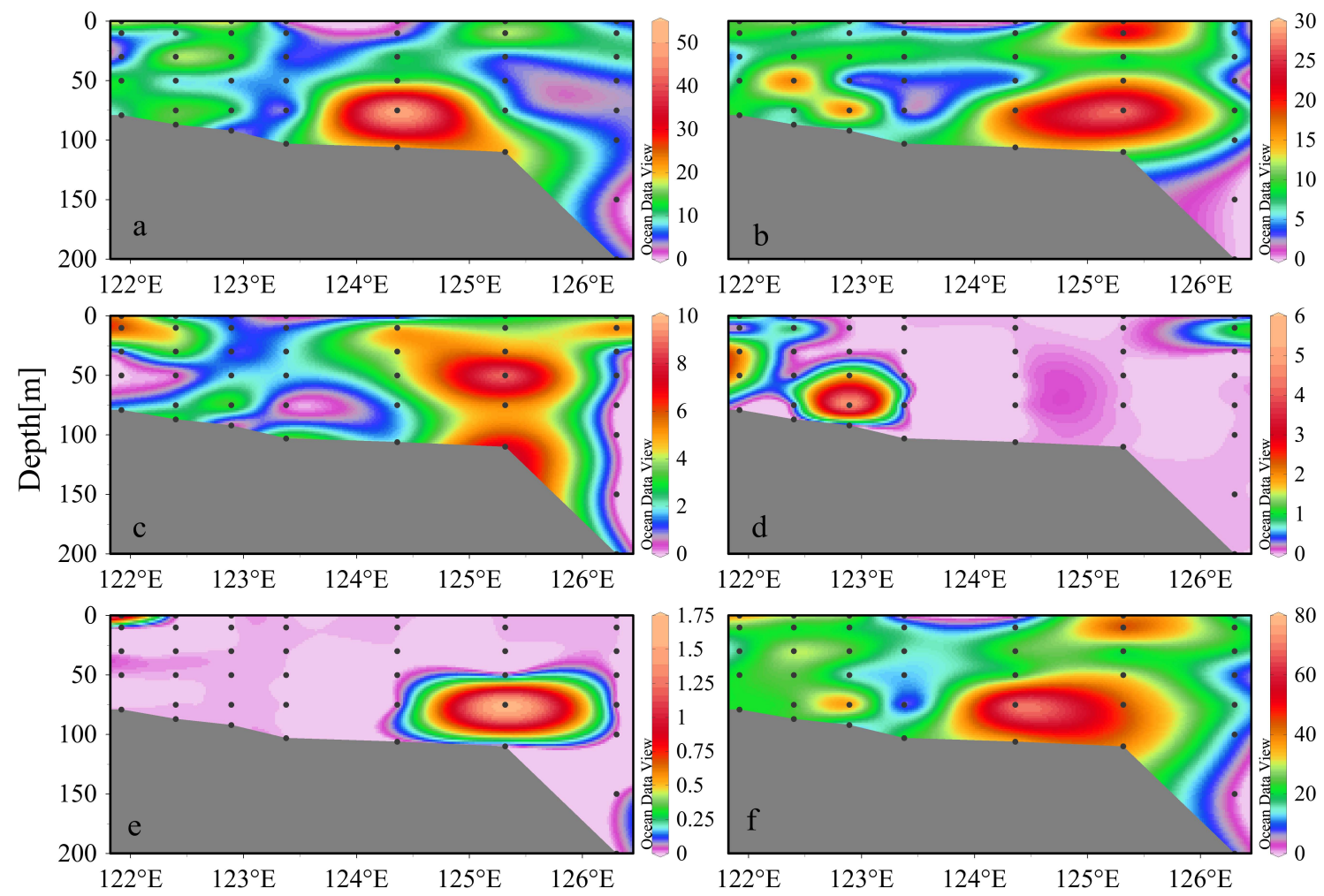

Fig. 24a. Vertical distribution of coccosphere abundance along section E in winter (unit: coccoliths $\mathrm{mL}^{-1}$ ). (a) Gephyrocapsa oceanica; (b) Emiliania huxleyi; (c) Algirosphaera robusta; (d) Helicosphaera carteri; (e) Calcidiscus leptoporus; and (f) sum. 


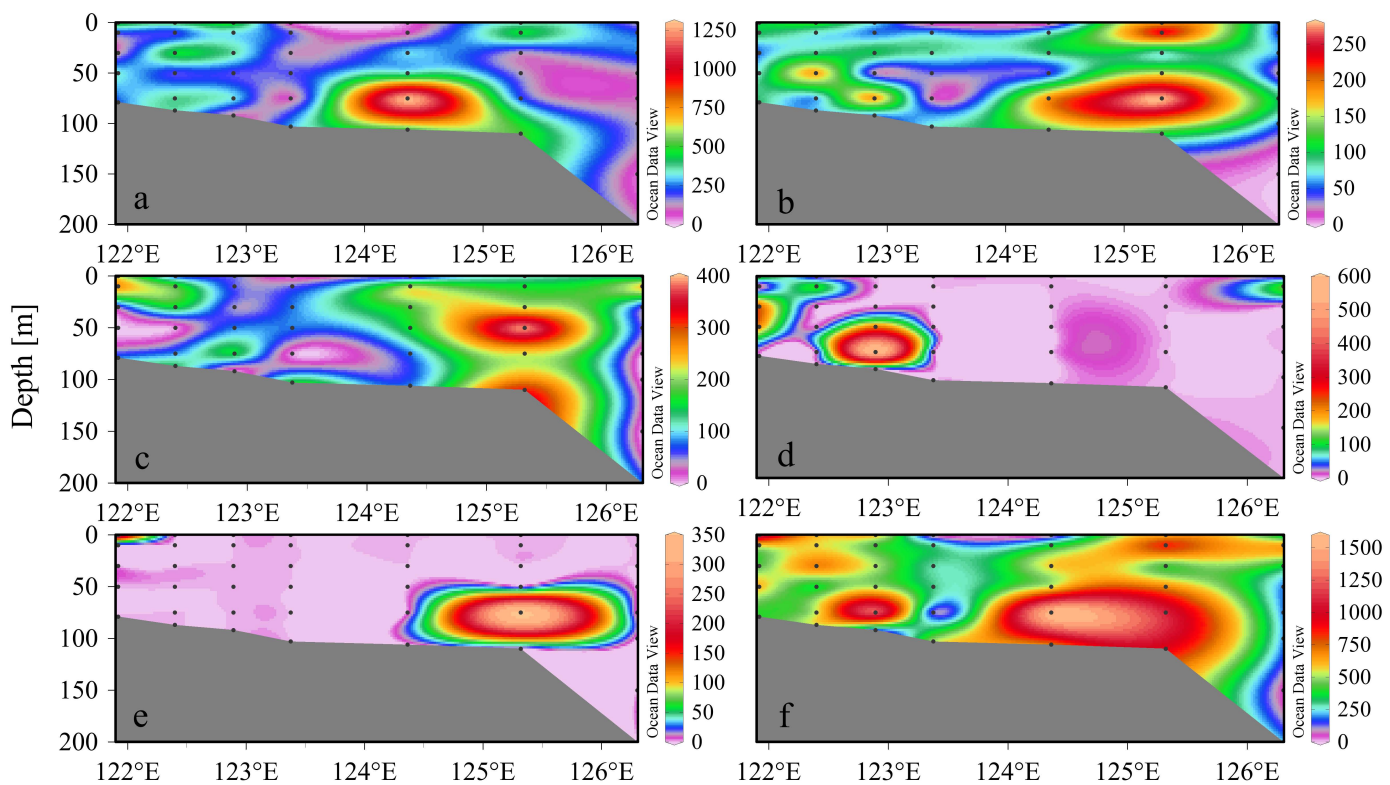

Fig. 24b. Vertical distribution of coccolithophore carbon biomass along section $\mathrm{E}$ in winter (unit: $\mathrm{ugC} \mathrm{L}^{-1}$ ). (a) Gephyrocapsa oceanica; (b) Emiliania huxleyi; (c) Algirosphaera robusta; (d) Helicosphaera carteri; (e) Calcidiscus leptoporus; and (f) sum.

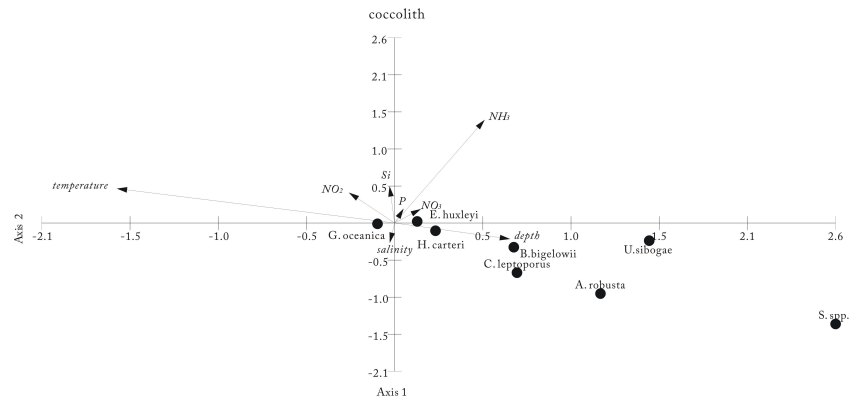

Fig. 25. Results of the CCA of coccolith abundance vs. environmental factors in summer ( $T$ : Temperature; $S$ : Salinity; $D$ : Sampling Depth; $\mathrm{NO}_{2}$ : Nitrite; $\mathrm{NO}_{3}$ : Nitrate; $\mathrm{NH}_{3}$ : Ammonium; Si: Silicate; $P$ : Phosphate; G.o: Gephyrocapsa oceanica; E.h: Emiliania huxleyi; H.c: Helicosphaera carteri; B.b: Braarudosphaera bigelowii; A.r: Algirosphaera robusta; C.1: Calcidiscus leptoporus; U.s: Umbilicosphaera sibogae; S.s.: Syracosphaera spp.).

trations are the decisive factors in summer. The abundance of coccoliths at all sections increased in various degrees as the sampling depth increased. The high value always appeared in the bottom layer, similar to the pattern reported by Sun et al. (2011) in the area of water column depth less than $200 \mathrm{~m}$ in the South China Sea, due to the resuspension of bottom sediment coccoliths and the coccoliths exfoliation after the dead cells sank to the bottom.

In winter, under the effects of monsoon, the water column is well mixed from surface to bottom, which leads to a relatively uniform vertical distribution of coccoliths. Therefore,

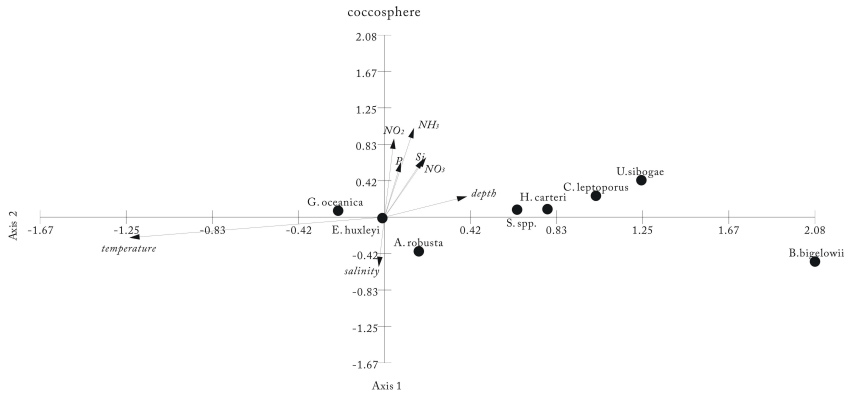

Fig. 26. Results of the CCA of coccosphere abundance vs. environmental factors in summer ( $T$ : Temperature; $S$ : Salinity; $D$ : Sampling Depth; $\mathrm{NO}_{2}$ : Nitrite; $\mathrm{NO}_{3}$ : Nitrate; $\mathrm{NH}_{3}$ : Ammonium; $\mathrm{Si}$ : Silicate; P: Phosphate; G.o: Gephyrocapsa oceanica; E.h: Emiliania huxleyi; H.c: Helicosphaera carteri; B.b: Braarudosphaera bigelowii; A.r: Algirosphaera robusta; C.1: Calcidiscus leptoporus; U.s: Umbilicosphaera sibogae; S.s.: Syracosphaera spp.).

the sampling depth is not the driving environmental factor in winter (Figs. 27 and 28).

Section P, from the Yangtze River estuary to southeast of the survey area, is affected by Yangtze River diluted waters and the Kuroshio waters, and the changing pattern of thermocline, halocline and nutrients is complicated in this area. It is always an important section for conducting research into the phytoplankton community dynamics (Liu, 2001). In summer, the increasing trend of coccoliths at section P from surface to bottom is obvious, with Gephyrocapsa oceanica as the absolutely dominating species. Higher abundances of both coccoliths and coccospheres were observed near the bottom of 


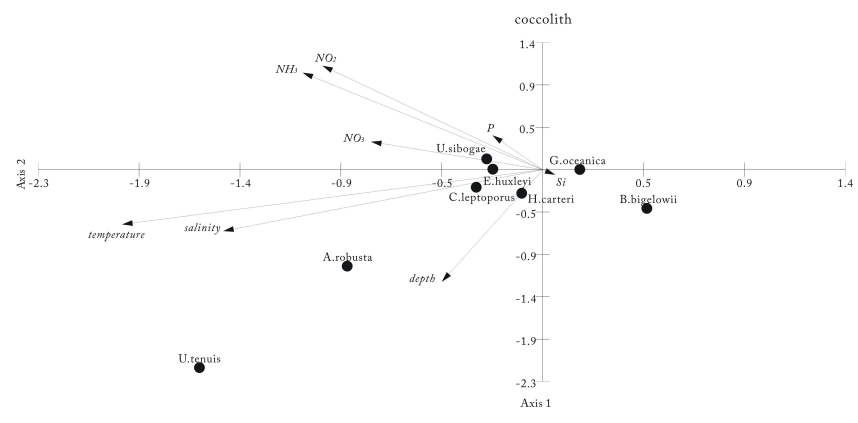

Fig. 27. Results of the CCA of coccolith abundance vs. environmental factors in winter ( $T$ : Temperature; $S$ : Salinity; $D$ : Sampling Depth; $\mathrm{NO}_{2}$ : Nitrite; $\mathrm{NO}_{3}$ : Nitrate; $\mathrm{NH}_{3}$ : Ammonium; Si: Silicate; P: Phosphate; G.o: Gephyrocapsa oceanica; E.h: Emiliania huxleyi; H.c: Helicosphaera carteri; B.b: Braarudosphaera bigelowii; A.r: Algirosphaera robusta; C.1: Calcidiscus leptoporus; U.s: Umbilicosphaera sibogae; U.t: Umbellosphaera tenuis).

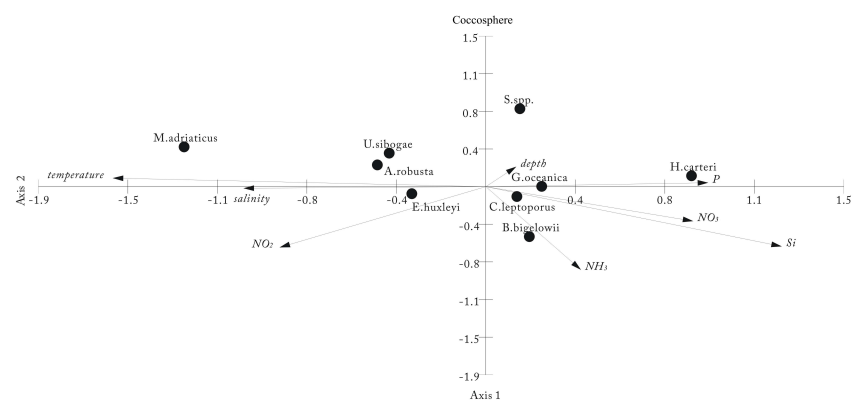

Fig. 28. Results of the CCA of coccosphere abundance vs. environmental factors in winter ( $T$ : Temperature; $S$ : Salinity; $D$ : Sampling Depth; $\mathrm{NO}_{2}$ : Nitrite; $\mathrm{NO}_{3}$ : Nitrate; $\mathrm{NH}_{3}$ : Ammonium; Si: Silicate; P: Phosphate; G.o: Gephyrocapsa oceanica; E.h: Emiliania huxleyi; H.c: Helicosphaera carteri; B.b: Braarudosphaera bigelowii; A.r: Algirosphaera robusta; C.1: Calcidiscus leptoporus; U.s: Umbilicosphaera sibogae; M.a: Michaelsarsia adriaticus; S.s.: Syracosphaera spp.).

the continental shelf, with high temperature, salinity and nutrient concentrations. Meanwhile, an obvious trend of sudden increase is the coccosphere abundance in the offshore area due to the high nutrient concentration on the bottom caused by the Kuroshio and its branch Taiwan warm current invading the East China Sea (Wang et al., 1998). In winter, the coccolith abundance increased slightly from the surface to bottom and suddenly decreased offshore. However, higher coccosphere abundance presented in the upper layers affected by upwelling.

By comparing the calculated carbon biomass and cell abundance distributions of LCs in the survey area, we found that most of the distribution patterns coincide well with each other for a specific species, except for one of the dominant species, Emiliania huxleyi. The biovolume of this species is relatively lower; therefore its contribution to the total carbon biomass is much lower even with a higher abundance. In ad- dition, the total LC organic carbon biomass contribution is generally lower than other phytoplankton functional groups in these areas (data not shown). This indicates that the major role of LCs in the Yellow Sea and the East China Sea is to contribute in the carbonate counter pump as a particle inorganic carbon producer, instead of the organic carbon pump.

Studies on LCs in a wide area of the Yellow Sea and the East China Sea of all seasons are still rare. There are still a lot of uncertainties on the understanding of the correlation between the dominated species as well as its abundance and the environmental factors. Further studies on the seasonal distribution of coccolithophores, its relationships with the environmental factors, and the succession between coccolithophores and other phytoplankton groups, such as diatoms, are still necessary for a comprehensive understanding of LC distribution in these areas in the future.

Acknowledgements. The authors would like to thank the captain and crew of Research Vessel Dong Fang Hong II for cruise helping for the National Program on Key Basic Research Project of China (2010CB428900). This research was supported by the National Program on Key Basic Research Project of China (No. 2009CB421202), the Program for New Century Excellent Talents in University (No. NCET-12-1065) and the National Natural Science Foundation of China (nos. 41176136, 41276124, 40776093 and 40676089) to Jun Sun, and the National Natural Science Foundation of China (No. 41306118) to Yuanyuan Feng.

Edited by: C.-K. Kang

\section{References}

Andruleit, H., Stager, S., Rogalla, U., and Cepek, P.: Living coccolithophores in the northern Arabian Sea: ecological tolerances and environmental control, Mar. Micropaleontol., 49, 157-181, 2003.

Baumann, K. H., Andruleit, H. A., Böckel, B., Geisen, M., and Kinel, H.: The significance of extant coccolithophores as indicators of ocean water masses, surface water temperature, and paleoproductivity: a review, Paläontolog. Zeitschr, 79, 93-112, 2005.

Bollmann, J., Cortes, M. Y., Haidar, A. T., Brabec, B., Close, A., Hofmann, R., Palma, S., Tupas, L., and Thierstein, H. R.: Techniques for quantitative analyses of calcareous marine phytoplankton, Mar. Micropaleontol., 144, 163-185, 2002.

Braak, C. J. F.: Canonical correspondence analysis: a new eigenvector technique for multivariate direct gradient analysis, Ecology, 67, 1167-1179, 1986.

Brown, C. W. and Yoder, J. A.: Coccolithophorid blooms in the global ocean, J. Geophys. Res., 99, 7467-7482, 1994.

Chen, C. T. A.: The Kuroshio intermediate water is the major source of nutrients on the East China Sea continental shelf, Oceanol. Acta, 19, 523-527, 1996.

Eppley, R. W., Reid, F. M. H., and Stickland, J. D. H.: Estimates of phytoplankton crop size, growth rate and primary production, Bull. Scripps Inst. Oceanogr. Univ. Calif. 17, 33-42, 1970. 
Frada, M., Young, J., Cachão, M., Lino, S., Martins, A., Narciso, Á., Probert, I., and Vargas, C. D.: A guide to extant coccolithophores (Calcihaptophycidae, Haptophyta) using light microscopy, J. Nannoplankt. Res., 31, 58-112, 2010.

Furuya, K., Kurita, K., and Odate, T.: Distribution of phytoplankton in the East China Sea in winter of 1993, J. Oceanogr., 52, 323333, 1996.

Furuya, K., Hayashi, M., Yabushita, Y., and Ishikawa, A.: Phytoplankton dynamics in the East China Sea in spring and summer as revealed by HPLC-derived pigment signatures, Deep-Sea Res., 50, 367-387, 2003.

Heimdal, B. R.: Chapter 6 - Modern Coccolithophorids, edited by: Tomas, C. R., Identifying Marine Phytoplankton, San Diego, Academic Press, 731-831, 1997.

Holligan, P. M., Viollier, M., Harbour, D. S., Camus, P., and Champagne, P. M.: Satellite and ship studies of coccolithophorid production along a continental shelf edge, Nature, 304, 339-342, 1983.

Hulburt, E. M.: Phytoplankton in the southwestern Sargasso Sea and North Equatorial Current, February 1961, Limnol. Oceanogr., 7, 307-315, 1962.

Hulburt, E. M.: Distribution of phytoplankton in coastal waters of Venezuela, Ecology, 44, 169-171, 1963a.

Hulburt, E. M.: The diversity of phytoplanktonic populations in oceanic, coastal, and estuarine regions, J. Mar. Res., 21, 81-93, $1963 b$.

Hulburt, E. M.: Succession and diversity in the plankton flora of the western North Atlantic, Bull. Mar. Sci., 14, 33-44, 1964.

Hulburt, E. M.: Competition for nutrients by marine phytoplankton in oceanic, coastal, and estuarine regions, Ecology, 51, 475-484, 1970.

Hulburt, E. M.: Description of phytoplankton and nutrient in spring in the western North Atlantic Ocean, J. Plankton Res., 12, 1-28, 1990.

Jin, S. F. and Sun, J.: The distribution of living coccolithophore in East China Sea in autumn, 2010, Acta Oceanol. Sin., 33, 120131, 2013 (in Chinese with English abstract).

Jordan, R. W., Cros, L., and Young, J. R.: A revised classification scheme for living haptophytes, Micropaleontol., 50, 55-79, 2004.

Liu, X. Q.: Distribution on features of T-S and chemical constituents at the PN section in the East China Sea during summer, Oceanol. Limnol. Sin., 32, 1-9, 2001 (in Chinese with English abstract).

Liu, Z. L. and Hu, D. X.: Preliminary study on the Huanghai Sea coastal current and its relationship with local wind in summer, Acta Oceanol. Sin., 31, 1-7, 2009 (in Chinese with English abstract).

Luan, Q. S.: Study on summer and winter living coccolithophores and calcification rates in the coastal China Seas, Dissertation, Ocean University of China, 2010 (in Chinese with English abstract).

Marshall, H. G.: Observations on Vertical distribution of coccolithophores in the northwestern Sargasso Sea, Limnol. Oceanogr., 11, 432-435, 1996.

Marshall, H. G.: Coccolithophorids in the Northwest Sargasso Sea, Limnol. Oceanogr., 13, 370-376, 1968.

Marshall, H. G.: Phytoplankton distribution off the North Carolina coast, Am. Midl. Nat., 82, 241-257, 1969a.
Marshall, H. G.: Observations on the spatial concentrations of phytoplankton, Castanea, 34, 217-222, 1969 b.

Marshall, H. G.: Phytoplankton observations in the eastern Caribbean Sea, Hydrobiologia, 41, 45-55, 1973.

Marshall, H. G.: Phytoplankton distribution along the eastern coast of the USA. I. Phytoplankton composition, Mar. Biol., 38, 81-89, 1976.

Mohan, R., Mergulhao, L. P., Guptha, M. V. S., Rajakurnar, A., Thamban, M., AnilKurnar, N., Sudhakar, M., and Ravindra, R.: Ecology of coccolithophores in the Indian sector of the Southern Ocean, Mar. Micropaleontol., 67, 30-45, 2008.

Okada, H.: Modern coccolithophorid in the Pacific Ocean, Dissertation, Hokksido University, Sapporo, Japan, 1971.

Okada, H. and Honjo, S.: Distribution of coccolithophores in marginal seas along Western Pacific Ocean and in Red-sea, Mar. Biol., 31, 271-285, 1975.

Paasche, E.: A review of the coccolithophorid Emilianiahuxleyi (Prymnesiophyceae), with particular reference to growth, coccolith formation, and calcification-photosynthesis interactions, Phycologia, 40, 503-529, 2001.

Riley, G. A.: Phytoplankton of the north central Sargasso Sea, 1950-52, Limnol. Oceanogr., 2, 252-270, 1957.

Sun, J.: Organic carbon pump and carbonate counter pump of living coccolithophorid, Adv. Earth Sci., 22, 1231-1239, 2007 (in Chinese with English abstract).

Sun, J. and Liu Y.: Geometric models for calculating cell biovolume and surface area for phytoplankton, J. Plankton Res., 25, 13311346, 2003.

Sun, J., Liu, D. Y., and Ning, X. R.: Phytoplankton in the Prydz Bay and the adjacent Indian sector of the southern ocean during the austral summer 2001/2002, Oceanol. Limnol Sin., 34, 519-532, 2003 (in Chinese with English abstract).

Sun, J., An, B. Z., Dai, M. H., and Li, T. G.: Living coccolithophores in the Western South Chinasea in summer 2007, Oceanol. Limnol Sin., 42, 170-178, 2011 (in Chinese with English abstract).

Wang, F.: Nitrate and phosphate conditions and fishery resources in the offshore area of the East China Sea, Res. Sci., 30, 1-8, 2008 (in Chinese with English abstract).

Wang, P. X. and Cheng, X. R.: Calcareous nannoplankton in surface sediments of the East China Sea, Acta Oceanol. Sin., 10, 76-87, 1988 (in Chinese with English abstract).

Winter, A., Rost, B., Hilbrecht, H., and Elbrachter, M.: Vertical and horizontal distribution of coccolithophoresin the Caribbean Sea, Geo-Mar. Lett., 22, 150-161, 2002.

Yang, T. N., Wei, K. Y., and Gong, G. C.: Distribution of coccolithophorids and coccoliths in surface ocean off northeastern Taiwan, Bot. Bull. Acad Sinica, 42, 287-302, 2001.

Yang, T. N., Wei, K. Y., and Chen, L. L. Occurrence of coccolithophorids in the Notheastern and Central South China Sea, Tianwania, 48, 29-45, 2003.

Yang, T. N., Wei, K. Y., Chen, M. P., Jin, S. J., Gong, G. C., Lin, F. J., and Lee, T. Q.: Summer and winter distribution and malformation of coccolithophores in the East China Sea, Micropaleontology, 50, 157-170, 2004.

Zhang, H.: Distribution features of nutrients structure and nutrient limitation in the north of Yellow Sea, J. Ocean Univ. China, 39, 1-8, 2009 (in Chinese with English abstract). 
Zhang, J.: Study on Summer and Winter Community and Distribution of Living Coccolithophores in the Yellow Sea and East China Sea, Dissertation, Ocean University of China, 2011 (in Chinese with English abstract).
Zou, E. M. and Xiong, X. J.: Characteristics and Seasonal Variations of the Thermocline and Halocline in the Huanghai Sea and the East China Sea, J. Oceanogr. Huanghai Bohai Seas, 19, 1-11, 2011 (in Chinese with English abstract). 